\title{
Retrográd metamorfózishoz kapcsolódó fluidumok egy variszkuszi szubdukciós csatornában: fluidumzárvány-vizsgálatok a Cabo Ortegal Komplexum ultrabázisos kőzeteiben
}

\author{
SPRÁNITZ Tamás ${ }^{1 *}$, SZABó Csaba ${ }^{1}$, JóZSA Sándor $^{2}$, BERKESI Márta ${ }^{1}$ \\ 'Eötvös Loránd Tudományegyetem, Természettudományi Kar, Kőzettani és Geokémiai Tanszék, Litoszféra Fluidum Kutató Laboratórium, \\ 1117 Budapest, Pázmány Péter sétány 1/C \\ ${ }^{2}$ Eötvös Loránd Tudományegyetem, Természettudományi Kar, Kőzettani és Geokémiai Tanszék, \\ 1117 Budapest, Pázmány Péter sétány 1/C; *spratom.elte@gmail.com
}

\section{Retrograde metamorphic fluids preserved in a Variscan subduction channel: a fluid inclusion study in ultramafic rocks of the Cabo-Ortegal Complex, NW Spain}

Abstract

Subduction zone fluids play an essential role in large-scale transport processes between the down-going slab and the overlying upper mantle, inducing earthquakes and metasomatism. Fluid inclusions, trapped in high pressure rocks, originating from such environments, yield direct information on the nature and chemistry of these fluids. Here a description is given of the microstructural characteristics of secondary fluid inclusions in the amphibole and clinopyroxene of pyroxenites from the Cabo-Ortegal Complex (COC, NW Spain). This description is based on fluid inclusion petrography, microthermometry and Raman spectroscopy. Pyroxenites in this study were sampled from both main mantle sections of the COC (i.e. Herbeira and Limo Massif) and show various degrees of amphibolization and serpentinization. The clinopyroxene and amphibole host three types of secondary fluid inclusions, which were trapped before and during serpentinization. Type I inclusions are hosted by amphibole and form a negative crystal shape, consisting of $\mathrm{Ca}-\mathrm{Mg}$-carbonates and volatiles such as $\mathrm{N}_{2}$ and $\mathrm{CH}_{4}$. The vapour phase contains nitrogen and methane in various relative proportions $\left(\mathrm{CH}_{4}: 3-84 \mathrm{~mol} \%, \mathrm{~N}_{2}: 16-97\right.$ $\mathrm{mol} \%$ ). However, the irrelative concentration is consistent within a single healed fracture. Carbonates in this type of inclusion can be interpreted as products of a post-entrapment carbonation reaction which consumed $\mathrm{CO}_{2}$. Consequently, nitrogen and methane were enriched in the residual fluid. The originally trapped fluid in the amphibole could have been $\mathrm{CO}_{2}$-rich (min. 53.3-69.5 mol\%), based on mass balance calculations. Type II three-phase fluid inclusions are hosted by both clinopyroxene and amphibole with an elongated shape. They are halite-bearing aqueous inclusions with gas bubble-containing $\mathrm{N}_{2}$ and $\mathrm{CH}_{4}$ (N2: 73-87 mol\%, $\mathrm{CH}_{4}$ : 13-27 mol\%). Homogenization of the bubble to the liquid proceeded between 270 and $290{ }^{\circ} \mathrm{C}$. Cryogenic Raman spectroscopy confirmed no salt other than $\mathrm{NaCl}$ — verified by the presence of hydrohalite — with a salinity between 37-61 wt.\% $\mathrm{NaCl}$. Type III inclusions comprise irregular two-phase, liquid-rich aqueous inclusions with $\mathrm{CH}_{4}$ and, subordinately, $\mathrm{H}_{2}$ in the vapour phase. Homogenization of the vapour phase to liquid occurred between 220 and $270{ }^{\circ} \mathrm{C}$. No salt hydrate was detected (apart from water ice at $-196^{\circ} \mathrm{C}$, where micro-thermometry yielded a salinity of $2.4-7.9 \mathrm{wt} . \% \mathrm{NaCl}$ ). This type (i.e. the two-phase inclusions) is the most abundant one, present in almost every sample and, from a textural aspect, is clearly associated with serpentine veins in clinopyroxene and amphibole. (Types I and II predate type III inclusions.) These inclusions can be interpreted as representatives of the latest, pervasive serpentinizing fluid. The results obtained in the present study indicated that the examined rocks of the ultramafic series of the COC have been involved in multistage fluid migrations, with different respective chemical processes during the retrograde path of the metamorphic evolution of the series in a Variscan subduction channel.

Keywords: Cabo Ortegal Complex, fluid migration, subduction fluid, secondary fluid inclusion, serpentinization, microthermometry, Raman spectroscopy

Összefoglalás

Az exhumálódott, nagy nyomású metamorf terrénumok - mint a spanyolországi Cabo Ortegal Komplexum (COK) kőzetei közvetlen bizonyítékokkal szolgálnak a szubdukciós környezetben zajló fluidum-kőzet kölcsönhatásokról. Vizsgálataink fókuszában a COK két fő köpeny egységéből (Herbeira- és Limo-masszívum) származó amfiboltartalmú piroxenit kőzetek állnak, amelyek a szubdukciós csatornában zajló exhumációs folyamatok eredményeként eltérő mértékben gazdagodtak amfibolban, és szerpentinesedtek. A klinopiroxén és az amfibol több, a szerpentinesedést megelőző és azzal egyidejúleg csapdázódott másodlagos fluidumzárvány-típust tartalmaz. Munkánk célja a retrográd reakciók során, a szubdukciós környezetben kulcsfontosságú szerepet játszó fluidumok megismerése a másodlagos fluidumzárványok tanulmányozásával. 
A fluidumzárvány petrográfia alapján három másodlagos zárványtípust különítettünk el, amelyek három fő fluidummigrációs eseményt rögzítettek az alábbi feltételezhető kronológiai sorrendben: I.) $\mathrm{CO}_{2}$-gazdag, $\mathrm{N}_{2}$ - $\mathrm{CH}_{4}$-tartalmú fluidum, II.) $\mathrm{N}_{2}-\mathrm{CH}_{4}$-tartalmú, nagy sótartalmú vizes fluidum, III.) $\mathrm{CH}_{4}$-gazdag, alárendelten $\mathrm{H}_{2}$-tartalmú, enyhén sós fluidum. A Ca-Mg-karbonátokból és illó komponensekből $\left(\mathrm{CH}_{4}\right.$ és $\left.\mathrm{N}_{2}\right)$ álló I. típusú zárványok a csapdázódást követően a befogadó amfibol-fluidum $\left(\mathrm{CO}_{2}\right.$-gazdag, min. 53,3-69,5 mol\%) reakció eredményeként jöhettek létre. E folyamat során létrejött szilárd fázisokat ún. mostohaleány-ásványnak tekinthetjük. A szén-dioxidot fogyasztó karbonátképződés eredményeként a reziduális fluidum nitrogénben és metánban gazdagodott. A szobahőmérsékleten háromfázisú (szilárd, folyadék és gáz) II. típusú zárványok nagy szalinitású (kb. 37-61 wt.\% NaCl) vizes fluidumot csapdáztak, amelyben a nitrogén és alárendelten a metán is meghatátozó alkotórész. A vizsgált kőzetekben leggyakrabban előforduló, legfiatalabb zárványtípus (III.) klinopiroxénben, valamint amfibolban is jelen van. A szöveti bizonyítékok szerint az I. és II. típusú fluidumzárványok csapdázódása megelőzte a szerpentinesedést, míg a $\mathrm{CH}_{4}$-gazdag, alárendelten $\mathrm{H}_{2}$-tartalmú enyhén sós $(2,4-7,9$ wt.\% $\mathrm{NaCl})$ fluidumot reprezentáló III. típusú zárványok közvetlenül a szerpentinesedéshez kötődnek, ami a legkésőbbi, az egész kőzettani egységet átható szerpentinesedésért felelős fluidumként értelmezhető. Vizsgálataink alapján a COK ultrabázisos kôzetei olyan eltérô kemizmusú és többfázisú fluidummigrációs eseményekről tanúskodnak, amelyek másodlagos fluidumzárványok formájában a variszkuszi szubdukciós csatornában a retrográd metamorf út során csapdázódtak.

Tárgyszavak: Cabo Ortegal Komplexum, fluidummigráció, szubdukciós fluidum, másodlagos fluidumzárvány, szerpentinesedés, mikrotermometria, Raman-spektroszkópia

\section{Bevezetés}

A szubdukciós környezetben zajló anyagmozgás kulcsfontosságú szereplői a fluidumok, amelyek a szubdukálódó kôzetlemezből folyamatosan keletkeznek. Ennek oka az alábukó lemez előrehaladásához köthető nyomás- és hőmérsékletnövekedés, ami illótartalmú ásványok (pl. karbonátok, rétegszilikátok) stabilitásának felbomlását - így fluidumfelszabadulást - eredményezi. E folyamat a szubdukált lemez-köpeny határon és a köpenyékben jelentôs fizikai és kémiai kölcsönhatást vált ki: a litoszféra köpeny metaszomatózisát, földrengések kialakulását okozza, továbbá érctelepek keletkezéséhez is nagyban hozzájárul. Az orogén folyamatok és exhumálódás során olyan nagy nyomáson és hőmérsékleten képződött kőzettestek (pl.: eklogit, granulit) kerülhetnek felszínre, amelyek a szubdukcióhoz kötődő metamorfózis során alakultak ki (SCAMBELLURI \& PHILIPPOT 2001, ToureT 2001), és a bennük megőrzött kőzettani és geokémiai sajátosságok a szubdukció mechanizmusának megismerését teszik lehetővé. A nagy nyomáson lezajlott fluidum-kôzet kölcsönhatásokról közvetlen információt a szubdukált kôzetek ásványaiban csapdázódott fluidumzárványok szolgáltatnak. A fluidumzárvány-tanulmányok döntő többsége az elsődleges zárványokkal foglalkozik, amelynek segítségével a befogadó ásvány kristályosodásának fizikai körülményei és az egyidejűleg jelen lévő fluidumok ismerhetôk meg. Ezzel szemben a másodlagos fluidumzárványok a befogadó ásvány kialakulása utáni fluidumáramlási esemény(eke)t dokumentálják, amelyek deformáció (rekrisztallizáció), illetve az ásványokban keletkezett repedések beforrása során csapdázódtak (RoEDDER 1984). E másodlagos fluidumzárványok a retrográd metamorfózis során felszabaduló fluidumokról szolgáltathatnak ismereteket. Jelentőségük ellenére az elsődleges zárványokhoz képest lényegesen kevesebb tudással rendelkezünk róluk.

A COK ultrabázisos kőzeteirôl számos petrográfiai, főés nyomelem-, továbbá izotóp-geokémiai és szerkezetföldtani tanulmány készült (VoGEL 1967; GIL IBARGUCHI et al. 1990; GIRARDIEAU \& GIL IBARGUCHI 1991; ORDÓŃEZ
CASAdo et al. 2001; MARCos et al. 2002; SANTOS et al. 2002; Puelles et al. 2005, 2009; Albert et al. 2015; Tilhac et al. 2016, 2017, 2020). Korábbi vizsgálatok alapján a csúcsmetamorfózist követő exhumáció során többlépcsôs retrográd metamorf felülbélyegzés érte a $\mathrm{COK}$ ultrabázisos kôzeteit, amelynek során a kőzetek amfibolosodtak és szerpentinesedtek (TILHAC et al. 2016). Habár a COK ultramafikus kőzeteit ért szerpentinesedés különböző eredetú (hidrotermás, meteorikus) fluidumokhoz kötődhet (PEREIRA et al. 2008), a metamorf fejlődés során jelen lévő fluidumok közvetlen vizsgálatáról mindezidáig nem született tudományos közlemény.

A fluidumzárvány petrográfiai, mikrotermometriai és Raman-spektroszkópos elemzések alapján a piroxenitekben található klinopiroxén és amfibol több, a szerpentinesedést megelőzó és azzal egyidejúleg csapdázódott másodlagos fluidumzárvány-típust tartalmaz. Jelen tanulmány célja a COK ultrabázisos kôzeteinek retrográd folyamataiban kulcsfontosságú szerepet játszó fluidumok megismerése másodlagos fluidumzárványok vizsgálatával.

\section{Földtani háttér}

A COK az Ibériai-félsziget északnyugati peremén felszínre bukkanó allochton komplexumok egyike. Az allochton egységek az európai variszkuszi szutúrazóna maradványait képviselik, amelyek az Ibériai-félszigettől megszakítással a Cseh-masszívumig követhetôk (ALBERT et al. 2015). Ezeket a kőzetegységeket deformált, metamorf kőzetek alkotják, melyekbe több esetben granitoid kőzetek is benyomultak. Ezek alkotják azt az orogént, amely a késő paleozoikum során, pontosabban a késő devon - karbon időszakban a két fő kontinens: Laurázsia és Gondwana közeledése és ütközése eredményeként jött létre (MARTíNEZ CATAlÁn et al. 2009). Az ibériai allochton komplexumok olyan szubdukált kontinentális és óceáni litoszféra-fragmentumok együttesét képviselik, amelyek a hercini orogenezis során a Gondwana peremére obdukálódtak (ÁBALOS 
et al. 2003). A metamorf komplexum kőzetei többlépcsôs tektonotermális fejlődéssel alakultak ki a variszkuszi orogenezis során a szubdukciós csatornához kötődő progresszív és retrográd metamorfózis eredményeképp (MARTínez Catalán et al. 1997, Puelles et al. 2005). A nagynyomású eklogit-, granulit-, orto- és paragneisz-egységek mellett a tanulmányozott területen három ultramafikus masszívum - Limo, Herbeira és Uzal - található (1. ábra), egymással tektonikus határok mentén érintkezve (GIL IBARGUCHI et al. 1990). Az ultrabázisos egységek túlnyomórészt harzburgitból állnak, amelyben rétegszerúen piroxenit, dunit és kromitit is gyakran előfordul. Az ultramafikus egység szupraszubdukciós környezetben zajló olvadék-peridotit kölcsönhatás eredményeként jött létre 459-515 millió éve (SANTOS et al. 2002, TiLHAC et al. 2017). Ennek során egy Si-ban szegény (pikrites) olvadék nyomult be a litoszféraköpenybe és lépett kölcsönhatásba a befogadó harzburgittal (TILHAC et al. 2017). E folyamat eredményeként dunitek és kromititek, majd az olvadék differenciációja során a dunitet helyettesítve olivintartalmú klinopiroxenitek jöttek létre (TilHaC et al. 2017, 2020). A heterogén, piroxenitben gazdag köpenyék peridotit-egység később delaminá- lódott és benyomult a variszkuszi szubdukciós csatornába, ahol nagy nyomású és nagy hőmérsékletû metamorf felülbélyegzést szenvedett $\left(1,6-1,8 \mathrm{GPa}, \sim 800{ }^{\circ} \mathrm{C}\right)$, majd az eklogitos és granulitos kőzetegységekkel együtt exhumálódott (ÁBAlos et al. 2003, PuelLes et al. 2005, TilHAC et al. 2016, HENRY et al. 2017). Az eklogit fáciesú felülbélyegzés és deformáció ideje ( 390 millió év) megegyezik a COK többi HP-HT egységének csúcsmetamorf korával (ORDóŃEZ CASADO et al. 2001). A COK kőzeteit amfibolit és zöldpala fáciesú retrográd metamorfózis érte a szubdukciós csatornában zajló gyors exhumációs folyamatok során (ÁBALOS et al. 2003). A harzburgitban található erek és rétegek mentén előforduló piroxenitek gyakran üdék, azonban a nyírási zónák mentén a peridotit erôteljesen amfibolosodott, továbbá az ultrabázisos kőzetek túlnyomó része - elsősorban a harzburgit - nagymértékben szerpentinesedett (GIL IBARGUCHI et al. 1999).

A munkánkban bemutatott piroxenitminták a COK Limo- és Herbeira-masszívumaiból származnak (1. és 2. ábra). A korábbi munkák petrográfiai elemzésére és főelem-geokémiai eredményeire támaszkodva jelen tanulmány a vizsgált kőzetek fluidumzárványainak sajátosságait

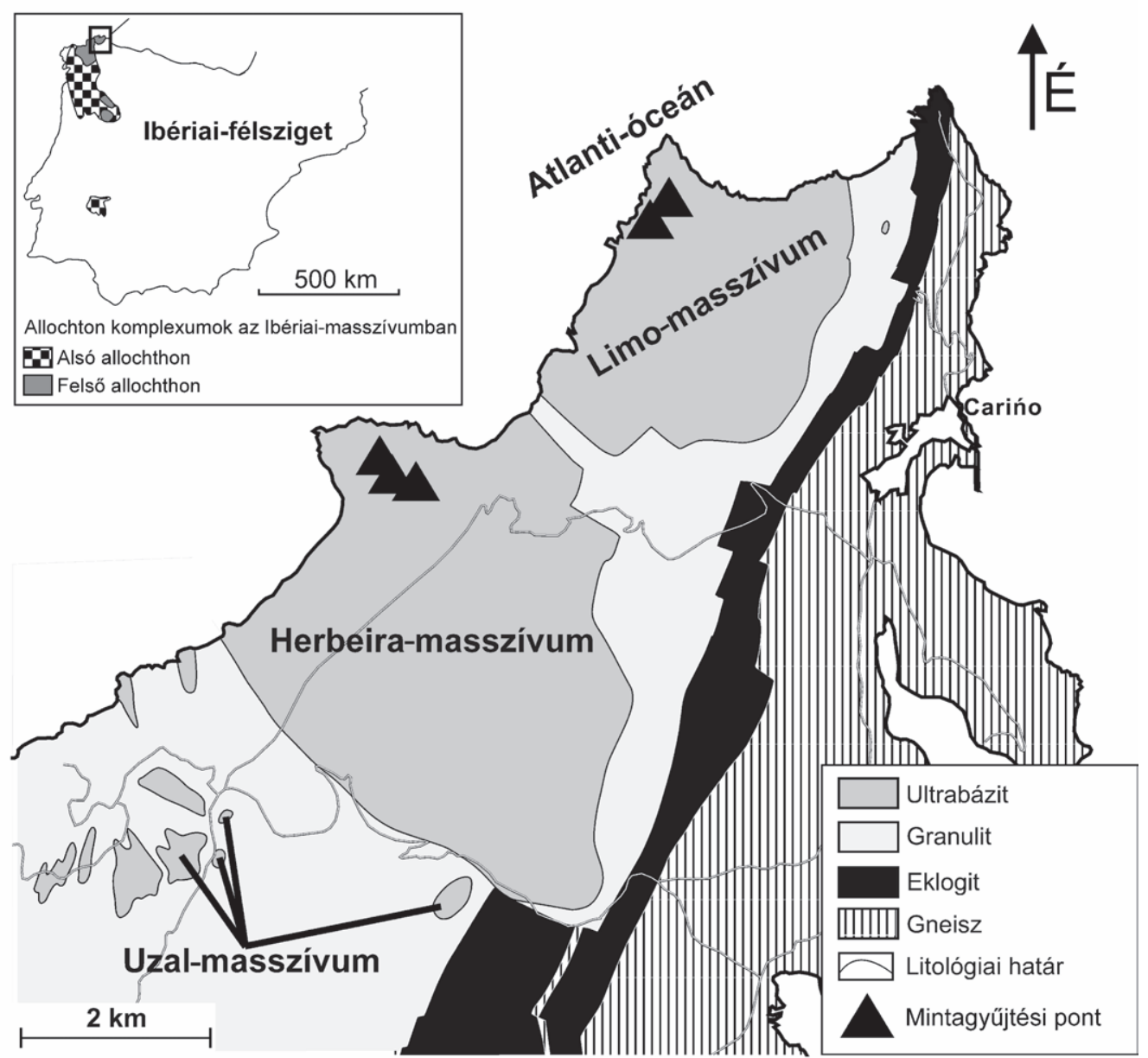

1. ábra. A vizsgált terület (COK) egyszerűsített földtani térképe és földrajzi elhelyezkedése ÁBALOS et al. (2011) után módosítva. A jelen munkában bemutatott minták (ultrabázisos kőzetek) gyüjtési pontjait fekete háromszögek jelölik

Figure 1. Schematic geological map and location of the studied area (COC), modified after ÁBALOS et al. (2011). Sampling points are indicated with black triangles 

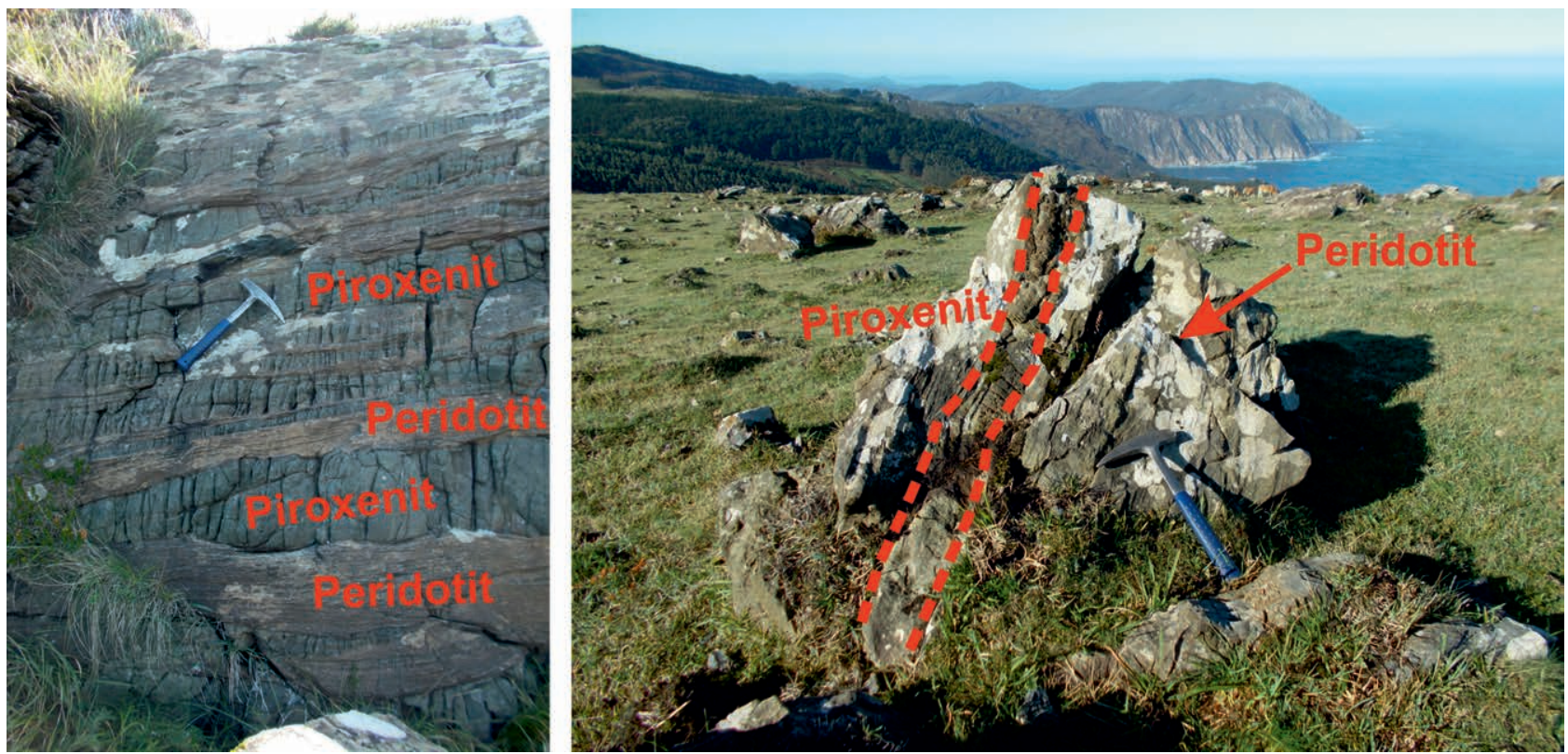

2. ábra. A vizsgált piroxenitrétegek jellegzetes terepi megjelenése a COK Herbeira-masszívumában

A közép- és durvaszemcsés piroxenit a szerpentinesedett és felszíni mállást szenvedett peridotittal (harzburgit) váltakozva, vagy abban ereket, rétegeket és lencséket formálva (piros szaggatott vonallal jelölve a jobb oldalon) fordul elő

Figure 2. Representative field occurrence and sampling points of the studied pyroxenites in the Herbeira Massif of the COC

Medium- to coarse-grained pyroxenites (marked with red dashed lines on the right) alternates with highly serpentinized peridotite (harzburgite) or occur as veins, layers or lenses included in it

és azok jelentőségét mutatja be. A COK piroxenit (klinopiroxenit, websterit és ortopiroxenit) közép-durvaszemcsés (2-5 mm), és gyenge foliációt mutat. A piroxenit granoblasztos-porfiroklasztos szövetú, túlnyomórészt klinopiroxénből áll, különböző mennyiségben ortopiroxént, olivint, spinellt és flogopitot tartalmaz (TILHAC et al. 2016). A klinopiroxén gyakran átalakult amfibollá (hornblende); akcesszióriák az ilmenit, klorit, epidot, Fe-Ni-szulfid és magnetit (GIRARDIEAU \& GIL IBARGUCHI 1991).

\section{Alkalmazott módszerek}

A terepi megfigyeléseket és mintagyújtést követően mind a petrográfiai, mind a fluidumzárvány-vizsgálatokhoz 34 mintából összesen 81 darab $100 \mu \mathrm{m}$ vastag, mindkét oldalán polírozott vastagcsiszolat készült. A mintaelőkészítés és a fluidumzárvány petrográfiai vizsgálatok az Eötvös Loránd Tudományegyetem Természettudományi Karának (ELTE TTK) Kőzettan-Geokémiai Tanszékén és a Litoszféra Fluidum Kutató Laboratóriumban (LRG) valósultak meg. A szöveti elemzés és a mikroszkópi fotók készítése egy Nikon CoolPix DS-Fi1 típusú kamerarendszerrel felszerelt Nikon OptiPhot2 típusú optikai mikroszkóppal történt. A kőzetalkotó ásványok főelemgeokémiai összetételének ellenőrzéséhez alkalmazott SEM-EDS elemzések kitúnő egyezést mutattak a szakirodalomban szereplő értékekkel (GIRARDIEAU \& GIL IBARUCHI 1991, TILHAC et al. 2016). A mikrotermometriai mérésekhez az LRG LINKAM THMS600 típusú, húthető-füthető tárgyasztalát használtuk. A húthető-füthető tárgyasztallal végzett kísérletek célja a különböző hőmérsékleteken le- zajló fázisátalakulások nyomon követése volt a II. és a III. típusú zárványokban. A múszer kalibrációja $\mathrm{H}_{2} \mathrm{O}-\mathrm{CO}_{2}$ tartalmú szintetikus zárványokkal történt, a mérési hiba $\pm 0,2^{\circ} \mathrm{C}$ volt. A fagyasztásos vizsgálatokhoz használt hûtőfolyadékként folyékony nitrogén szolgált, amely lehetôvé tette a $-196{ }^{\circ} \mathrm{C}$ történő hútést. A hútési ráta $5{ }^{\circ} \mathrm{C} /$ perc volt, továbbá a termális egyensúly kialakulásához 5 percig $-196{ }^{\circ} \mathrm{C}$-on tartottuk a hőmérsékletet. A melegítés során is $5{ }^{\circ} \mathrm{C} /$ perc sebességet használtunk, valamint a megfigyelt eutektikus, végsô olvadási és homogenizációs hőmérsékleteket közelítve $1{ }^{\circ} \mathrm{C} /$ perc fútési rátát alkalmaztunk a fázisátalakulások pontos rögzítéséhez. A szalinitást $\mathrm{NaCl}$ egyenértékben adtuk meg a $\mathrm{H}_{2} \mathrm{O}-\mathrm{NaCl}$ bináris rendszerben, melyet a BoDNAR (1993) által alkalmazott wt.\%-ként jelöltünk. A Ramanspektroszkópos mérések az ELTE TTK Központi Kutató és Ipari Kapcsolatok Centrumának HORIBA JobinYvon Labram HR800 típusú Nd-YAG lézer gerjesztőforrással ( = $532 \mathrm{~nm}$ ) felszerelt berendezésén valósultak meg. A Ramanspektroszkópos elemzés célja a fluidumzárványok szilárd, folyadék- és gázfázisainak meghatározása, mely kiegészíti, pontosítja a petrográfiai és mikrotermometriai megfigyeléseket (az eredmények összesítését 1. I. táblázat). A gázfázisok Raman-spektrumának segítségével megadható továbbá a fluidumkomponensek moláris részaránya, amelyet a Raman-csúcsok alatti integrált terület és az adott komponens Raman-hatáskeresztmetszetének függvényében számolunk ki (DuBESSY et al. 1989). A levegóben található nitrogén kontamináló hatásának kiszúréséhez a vizsgált zárványokkal megegyező mélységben végeztünk ellenőrző méréseket. A pontelemzéshez és térképezéshez az alábbi mérési paramétereket alkalmaztuk: 600, illetve 1800 rovátka/mm-es optikai rács, 50-100 m konfokális túlyuk, 
I. táblázat. Összefoglaló a vizsgált fluidumzárvány-típusok fő fizikai és kémiai paramétereiről a petrográfiai, mikrotermometriai és Raman-spektroszkópos elemzések alapján

Table I. Summary of the results on physical and chemical characteristics of the studied fluid inclusions, based on petrography, microthermometry and Raman spectroscopy

\begin{tabular}{|c|c|c|c|}
\hline & I. zárványtípus & II. zárványtípus & III. zárványtípus \\
\hline Mérések száma & 24 & 24 & 25 \\
\hline Fázisok $\left(\mathrm{T}=21^{\circ} \mathrm{C}\right)$ & szilárd + gáz & $\begin{array}{c}\text { szilárd + folyadék + } \\
\text { gáz }\end{array}$ & folyadék + gáz \\
\hline Befogadó ásvány & amfibol & $\begin{array}{c}\text { amfibol, } \\
\text { klinopiroxén }\end{array}$ & $\begin{array}{c}\text { amfibol, } \\
\text { klinopiroxén }\end{array}$ \\
\hline Eutektikus hőmérséklet & - & $-21,2--23,2^{\circ} \mathrm{C}$ & $-20,0--25,0^{\circ} \mathrm{C}$ \\
\hline $\begin{array}{l}\text { Végsổ jég olvadási } \\
\text { hômérséklet }\end{array}$ & - & $-0,5-0,0^{\circ} \mathrm{C}$ & $-1,4--5,0^{\circ} \mathrm{C}$ \\
\hline Homogenizációs hômérséklet & - & $270-290^{\circ} \mathrm{C}$ & $220-270^{\circ} \mathrm{C}$ \\
\hline Szilárd fázis & $\mathrm{Ca}-\mathrm{Mg}-\mathrm{karbonát}$ & halit & - \\
\hline Folyadékfázis & - & $\mathrm{H}_{2} \mathrm{O}-\mathrm{NaCl}$ & $\mathrm{H}_{2} \mathrm{O}-\mathrm{NaCl}$ \\
\hline Gázfázis & $\mathrm{N}_{2}+\mathrm{CH}_{4}$ & $\mathrm{~N}_{2}+\mathrm{CH}_{4}$ & $\mathrm{CH}_{4}+/-\mathrm{H}_{2}$ \\
\hline Illó komponensek aránya & $\begin{array}{c}\mathrm{CH}_{4}: 3-84 \mathrm{~mol} \% \text {, } \\
\mathrm{N}_{2}: 16-97 \mathrm{~mol} \%\end{array}$ & $\begin{array}{l}\mathrm{N}_{2}: 73-87 \mathrm{~mol} \%, \\
\mathrm{CH}_{4}: 13-27 \mathrm{~mol} \%\end{array}$ & $\begin{array}{c}\mathrm{CH}_{4}: 5-95 \mathrm{~mol} \% \\
\mathrm{H}_{2}: 5-95 \mathrm{~mol} \%\end{array}$ \\
\hline
\end{tabular}

100× objektív, 5-120 másodperc adatgyújtési idő, 2-3× ismétlés. 1800-as rácsozat esetén a spektrális felbontás $\leq 1 \mathrm{~cm}^{-1}$, míg a 600 -as esetén $\leq 3 \mathrm{~cm}^{-1}$ volt. A sóhidrátok meghatározásához alkalmazott módszer a kriogén Raman-spektroszkópia volt, amely ötvözi az előbbiekben ismertetett Ramanspektroszkóp és LINKAM hüthető-fúthető tárgyasztal mérési lehetőségeit. A kriogén Raman-spektroszkópos elemzések során a $-190{ }^{\circ} \mathrm{C}$-ig történô hûtést követôen a zárványokat szobahőmérsékletre melegítettük, majd az újbóli fagyasztáskor végeztük el a méréseket. A fagyasztás során megismételt hútési eljárás alkalmazása elősegíti, hogy az első fagyasztáskor képződött gyengén kristályos, metastabil fázisok a felmelegítés és újrahütést követően rendezett kristálytani szerkezetben, karakterisztikus Ramansávokkal kristályosodjanak (Ni et al. 2017). Az elemzés feldolgozása LabSpec v5.5 szoftverrel történt, amely lehetővé tette a zárványokban jelen lévő fázisok azonosításához a karakterisztikus Raman-sávok elkülönítését. A fázisok meghatározása BAUMGARTNER \& BAKKER (2010) és FrEzzoTti et al. (2012) munkái, illetve a nyílt hozzáférésú RRUFF adatbázis (LAUFENTE et al. 2015) használatával valósult meg.

\section{Eredmények}

\section{Petrográfia}

A terepmunka során elsődleges szempont volt azoknak a mintáknak a kiválasztása és begyújtése, amelyek lehetőség szerint a legkevésbé mutatták a felszíni mállás hatását. Ennek a feltételnek a Herbeira-masszívum északnyugati, a Limo-masszívum északi részén az átalakult harzburgitban húzódó 5-30 cm vastag, üde piroxenitrétegei bizonyultak leginkább megfelelőnek (2. ábra). A fluidumzárványvizsgálatokra kiválasztott piroxenitek domináns ásványai az 1-5 mm-es hipidiomorf klinopiroxén és alárendelten orto- piroxén, amelyhez a szemcsék között vagy zárványként megjelenő 10-100 um-es hipidomorf-xenomorf olivin, spinell és gránát társul. A piroxenit szubszekvens amfibolosodásának és szerpentinesedésének a szöveti megjelenései a következők: 1) sajátalakú amfibol ránövekedés és helyettesítés formájában (3. ábra, c), 2) szerpentinásványok érkitöltő pozícióban (3. ábra, a), illetve 3) kőzetalkotó ásványokat részben vagy egészben helyettesítve, pszeudomorfózákat alkotva. Megállapítható, hogy az amfibol nagy mennyiségben $(>50 \%)$ típusosan a foliált piroxenitekben jellemző, ritkán hornblenditet is formál. A vizsgált piroxenitek különböző mértékben szerpentinesedtek. Az átalakulás nemcsak mintánként, hanem a petrográfiai elemzés alapján kőzetalkotó ásványonként is eltérő mértékû: az olivin erôsen, az ortopiroxén mérsékelten, míg a klinopiroxén és az amfibol a legkevésbé szerpentinesedett.

\section{Fluidumzárvány petrográfia}

A polarizációs mikroszkópos szöveti elemzés alapján másodlagos fluidumzárványok klinopiroxénben és amfibolban fordulnak elő. A zárványok olyan beforrt repedések mentén helyezkednek el (3. ábra, c), amelyek a szemcsék szegélyéig (esetenként több szemcsén keresztül) követhetők. Ez az amfibol esetén többnyire a hasadási síkok orientációjával egyezik meg. Szobahőmérsékleti fázisegyütteseik alapján három különböző másodlagos fluidumzárvány-típust lehetett elkülöníteni: I. típus: szilárd + gázfázisú zárványok, II. típus: szilárd + folyadék- + gázfázisú zárványok és III. típus: folyadék- + gázfázisú zárványok. Az erôteljesen szerpentinesedett mintákban kizárólag a III. típusú másodlagos zárványtípus található, míg a többi zárványtípus (I. és II.) csak a kis mértékben szerpentinesedett mintákban jelenik meg. Az I. és II. zárványtípusokra jellemző, hogy a fázisarányok állandók, a zárványok mérete és alakja a beforrt repedések mentén 

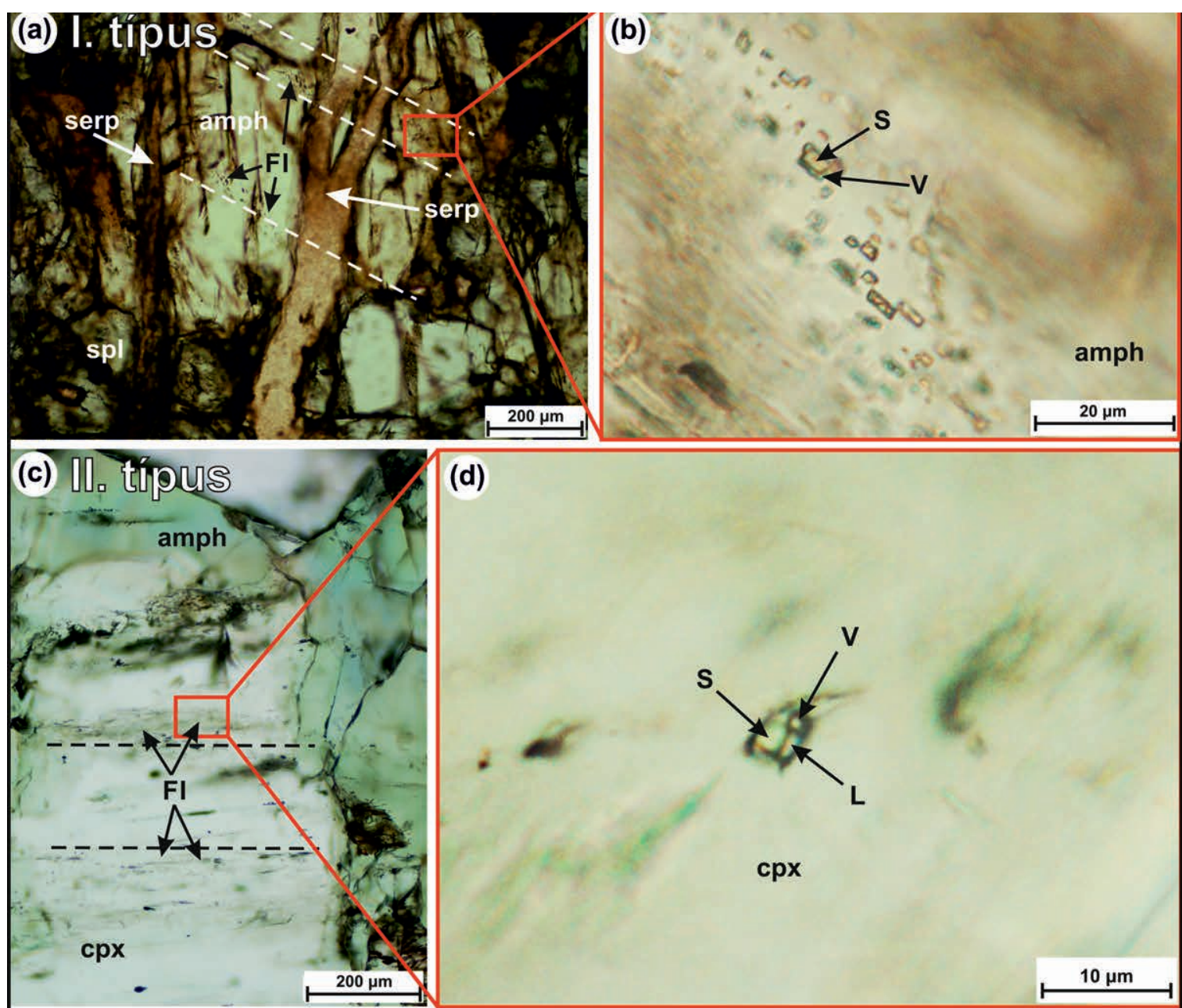

(d)
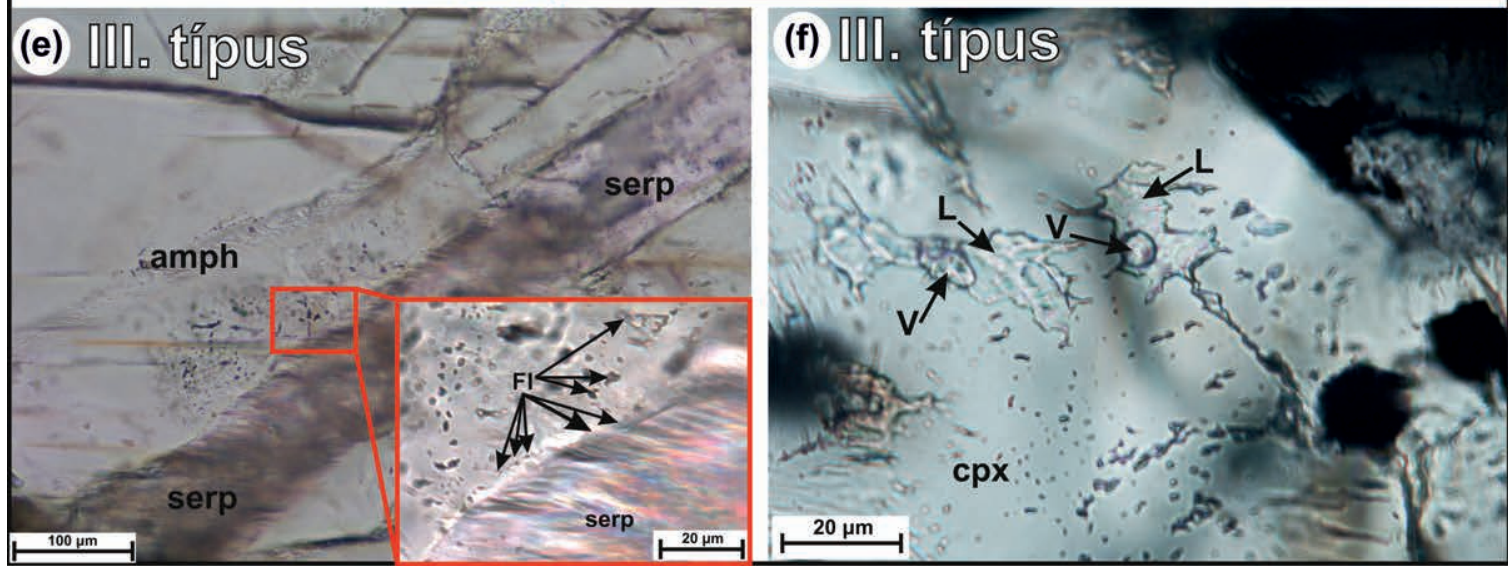

3. ábra. A COK piroxenitjeiben vizsgált zárványtípusok jellegzetes polarizációs mikroszkópi képek (1N, áteső fény)

a) Másodlagos, beforrt repedések mentén látható fluidumzárvány-sorok (I. típus) amfibolban, amelyek síkjait (fehér szaggatott vonalakkal jelezve) a kőzetet átszelő szerpentinerek harántolják. b) Az a) ábrán jelölt terület nagy nagyítású részlete. Az amfibolban csapdázódott I. típusú fluidumzárványok kétfázisúak és negatív kristály alakúak. A zárványokat szilárd fázis és gázfázis építi fel. c) A szemcse szegélyein amfibolosodó klinopiroxénben csapdázódott másodlagos fluidumzárványok (II. típus). d) A c) ábrán bekeretezett terület kinagyított képe. A II. típus hosszúkás alakú, háromfázisú fluidumzárványai. A szilárd fázis (sókocka?) mellett folyadékfázis, és gázfázis különíthető el. e) A III. típusú fluidumzárványok egyik jellegzetes szöveti sajátossága: a fluidumzárványok elterjedése közvetlenül a szerpentinerekhez kötődik, a zárványok azok mentén csapdázódtak. f) Szabálytalan, zegzugos alakú, kétfázisú fluidumzárványok (III. típus). Röviditések: FI fluidumzárvány, amph - amfibol, cpx - klinopiroxén, serp - szerpentinásványok, spl - spinell, S - szilárd fázis, L - folyadékfázis, V - gázfázis

Figure 3. Photomicrographs showing characteristic petrographical features of the studied fluid inclusion types in pyroxenites of the COC (plane polarized, transmitted light)

a) Secondary fluid inclusion trails (Type I) along healed fractures of amphibole (marked with white dashed lines) which are crosscut by later serpentine veins. b) Close-up view of the area marked on a). Type II secondary fluid inclusions are two-phase and negative crystal-shaped. They are made up by a solid phase and a vapor phase. c) Secondary fluid inclusions (Type II) trapped in amphibolized clinopyroxene. d) Close-up view of the area marked on c). Secondary inclusions of Type II are three-phase with an elongated shape. Solid phase (cubic salt) is surrounded by liquid and a vapor phase. e) Type III inclusions are texturally associated with serpentine veins as they are often located along them.f) Type III inclusions are secondary in origin, two-phase and having irregular and patchy shape. Abbreviations: FI - fluid inclusion, amph - amphibole, cpx - clinopyroxene, serp - serpentine minerals, spl - spinel, $S$ - solid phase, $L$ - liquid phase, $V$ - vapor phase 
azonos, tehát homogén fázisállapotú anyaoldatot feltételezhetünk (3. ábra, b, d). A III. típusnál azonban a változó alak és méret mellett gyakran megfigyelhetők lefűződések (3. ábra,f).

Az I. típusként jelölt zárványcsoportra a szöveti megfigyelés azt jelzi, hogy a másodlagos zárványok csapdázódása a szerpentinerek kialakulását megelőzően történhetett, lévén a szerpentinerek metszik a zárványok síkját (3. ábra, a). A megnyúlt, negatív kristály alakú zárványok befogadó ásványa amfibol. Az 1-12 um-es méretû, kétfázisú zárványok keresztezett nikolokkal vizsgálva idiomorf, magas interferenciaszínnel jellemezhetô, anizotróp fázist tartalmaznak (3. ábra,b). E szilárd fázis a zárványok térfogatának kb. 60-75\%-át teszi ki.

A II. típusú fluidumzárványok mérete 1-8 $\mu \mathrm{m}$, és hosszúkás, szabálytalan alakúak. A zárványok klinopiroxén és amfibol beforrt repedései mentén helyezkednek el (3. ábra, c). A kocka alakú szilárd fázis (sókocka) keresztezett nikolok között izotróp, amely mellett folyadék- és gázfázis van jelen (3. ábra, d).

A III. zárványtípus képviselői szabálytalan, zegzugos, amőbaszerú alakúak (3. ábra, $e-f)$. Méretuik 1 és 40 um. Befogadó ásványuk a klinopiroxén és az amfibol, de esetenként ortopiroxénben is megtalálhatók (3. ábra, e-f). Előfordulásuk szövetileg a szerpentinerekhez kötődik: a zárványok sok esetben azok mentén helyezkednek el (3. ábra, e). A nagy mértékben szerpentinesedett mintákban elterjedésük gyakran nem kötődik közvetlenül a szerpentinerekhez, hanem a kőzetalkotó ásványokban nagy mennyiségben „felhőszerúen”, beforrt repedések mentén helyezkednek el (3. ábra,f).

\section{Mikrotermometria}

A mikrotermometriai eredmények összefoglalását az $I$. táblázat foglalja össze. A zárványokat először hútöttuik, azonban még - $196{ }^{\circ} \mathrm{C}$-on sem lehetett az esetleges fagyasztás során keletkezô szilárd fázisokat a zárványok kis mérete miatt megfigyelni. A fagyasztást követő lassú melegítés hatására bekövetkező eutektikus olvadás kezdetét a gázbuborék megmozdulása jelezte, ami egyben a zárványban koegzisztens folyadékfázis jelenlétét is mutatja. Az eutektikus olvadási hőmérsékletek a II. típusú fluidumzárványokban $-21,2$ és $-23,2{ }^{\circ} \mathrm{C}$ között, míg a III. típus zárványaiban $-25,0$ és $-20,0{ }^{\circ} \mathrm{C}$ között adódtak. Végsô jégolvadás alatt a szilárd fázis teljes megolvadását értjük. Ezt a jelenséget a zárványok kis mérete miatt a II. zárványtípusban csak kriogén (fagyasztásos) Raman-spektroszkópiával sikerült megfigyelni, melyet a hidrohalit fó csúcsának $\left(3422 \mathrm{~cm}^{-1}\right)$ eltûnése jelzett. A fázisátalakulás a II. típusban $-0,5$ és $0,0{ }^{\circ} \mathrm{C}$, a III. típusban $-5,0$ és $-1,4{ }^{\circ} \mathrm{C}$ közötti hőmérséklet-tartományban zajlott. A végsô jégolvadást követôen a zárványokban folyadék- és gázfázis volt jelen és a további melegítés során a gázfázis térfogata folyamatosan csökkent mindaddig, míg eltúnésével a folyadékfázisba nem homogenizálódott. Ez a jelenség a II. típusban 270-290 C, míg a III. fluidumzárvány-típusban 220-270 ${ }^{\circ} \mathrm{C}$ hőmérsékleti tartományban játszódott le.
A II. típus esetén a kősókocka folyadékfázisba való homogenizációját a melegítés során nem sikerült megfigyelni, mert a sókocka nem oldódott fel a 295-300 ${ }^{\circ} \mathrm{C}$-os (dekrepitációs) hőmérsékletig.

A III. típus zárványainál megfigyelhető továbbá, hogy a 2-3 $\mu$ m-nél kisebb méretû lefüződésekben - melyek fázisarányainak meghatározása optikailag korlátozott - is a nagyobb, jól vizsgálható zárványokkal megegyező hőmérsékleteken történt fázisátalakulás, tehát ez alapján ennél a típusnál is állandó fázisarányokra (homogén fázisállapotú anyaoldatra) következtethetünk.

\section{Raman-spektroszkópia}

\section{I. típusú fluidumzárványok}

Karakterisztikus Raman-sávjaik (282, 713, 1087 cm-1) alapján a zárványok másod-harmadrendú interferenciaszínnel jellemezhető szilárd fázisa (3. ábra, b) karbonátnak azonosítható (4. ábra, a), amely kalcit szerkezettel és Ca-ban gazdag összetétellel jellemezhető, amiben min. 4$10 \% \mathrm{MgCO}_{3}$ komponens is jelen van (BISCHOFF et al. 1985 , BorRoMEO et al. 2017 eredményeivel összhangban). Kimutatható, hogy a Mg beépülésével közvetlen összefüggést mutat a kalcitszerkezetú karbonátokra jellemző fő csúcspozíciók helyzete, így azok nagyobb Mg-tartalom esetén nagyobb Raman-eltolódásértékeket vesznek fel a tiszta kalcitéhoz $\left(281,711,1085 \mathrm{~cm}^{-1}\right)$ képest (BORROMEO et al. 2017). A gázfázis nitrogén $\left(2328 \mathrm{~cm}^{-1}\right)$ és metán $\left(2917 \mathrm{~cm}^{-1}\right.$ ) elegyeként azonosítható (4. ábra, b-c), amely komponensek jelenléte állandó, azonban egymáshoz viszonyított arányuk változó (5. ábra). Az egyes zárványsorokon belül a zárványok ugyanolyan részarányban tartalmazzák a fluidumfázisokat, de a zárványsorok között (akár azonos szemcsén belül) lényeges eltérés mutatkozik. Ennek megfelelően a fluidumfázis nitrogénben vagy metánban gazdag összetételt is mutathat $\left(\mathrm{CH}_{4}: 3-84 \mathrm{~mol} \%\right.$, $\mathrm{N}_{2}$ : 16-97 mol\%), és e két szélsőtag között változik a két komponens aránya (5. ábra).

\section{II. típusú fluidumzárványok}

A mikrotermometriai megfigyelésekkel összhangban a Raman-spektroszkópia megerôsítette, hogy a szilárd fázis kősókocka, amelynek összetétele közel tiszta $\mathrm{NaCl}$, ugyanis a fagyasztásos vizsgálatok során a hidrohaliton ( $\mathrm{NaCl} \times$ $\left.2 \mathrm{H}_{2} \mathrm{O}\right)$ kívül más sóhidrát jelenlétére nem találtunk bizonyítékot (4. ábra, d). A hidrohalit karakterisztikus Ramanspektrumát (fó csúcsai: 3405, 3422, $3435 \mathrm{~cm}^{-1}$ ) a második, megismételt fagyasztáskor tudtuk azonosítani, míg első fagyasztáskor a hidrohalit fő csúcsaival megegyezô spektrális tartományban egy széles sáv jelent meg csupán, mely alig kristályos/amorf anyag jelenlétére utal (4. ábra, d). Megfigyelhető továbbá a fagyasztás során keletkező $\mathrm{H}_{2} \mathrm{O}$ jég karakterisztikus Raman-sávja, így megállapítható, hogy a folyadékfázist dominánsan víz alkotja. A gázfázis nitrogénben gazdag, metántartalmú összetételt mutat $\left(\mathrm{N}_{2}\right.$ : 73-87 $\mathrm{mol} \%, \mathrm{CH}_{4}$ : $13-27 \mathrm{~mol} \%$ ). 

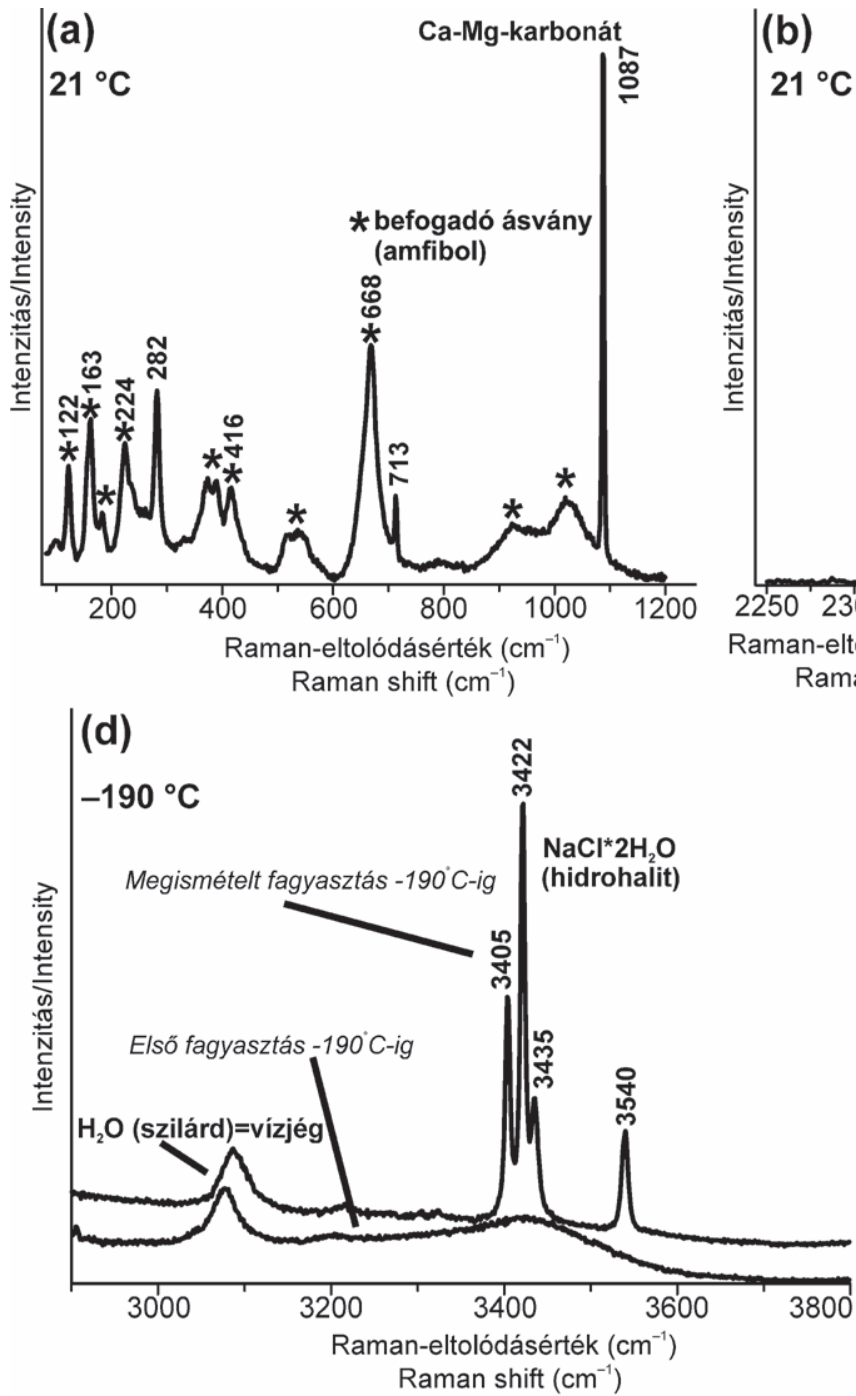

(b)

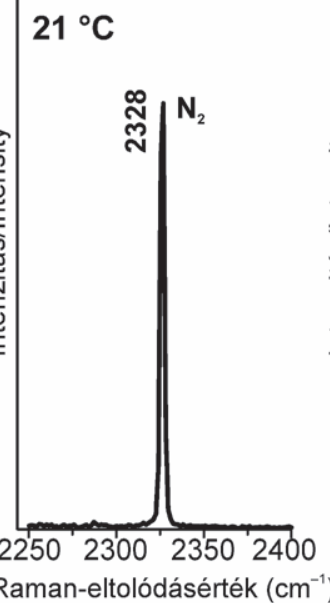

Raman shift $\left(\mathrm{cm}^{-1}\right)$
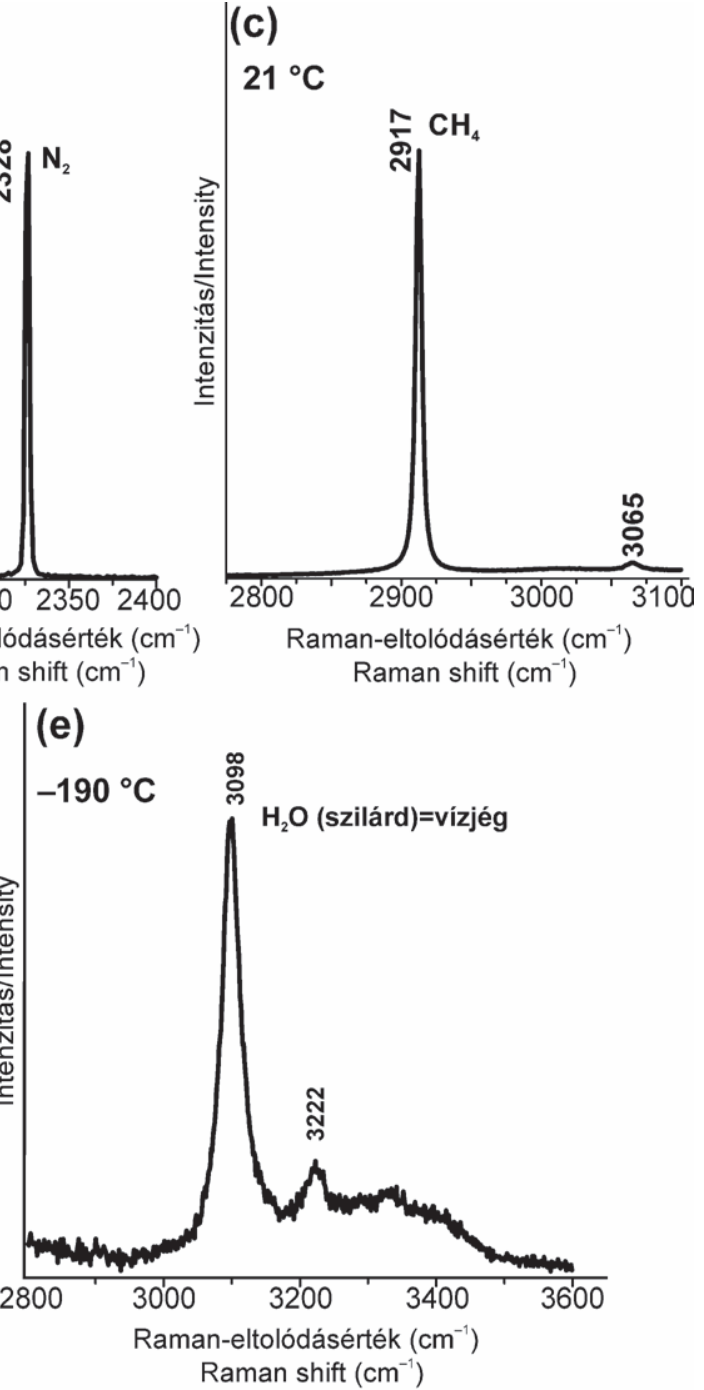

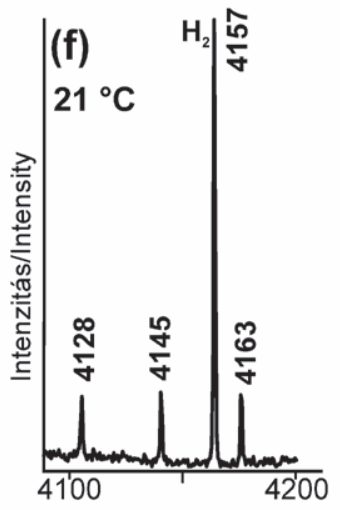

Raman-eltolódásérték $\left(\mathrm{cm}^{-1}\right)$ Raman shift $\left(\mathrm{cm}^{-1}\right)$

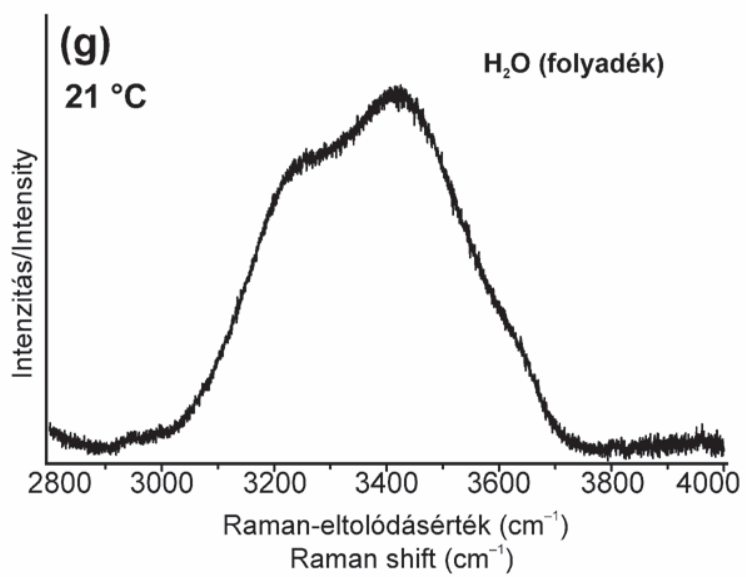

4. ábra. A vizsgált fluidumzárványok szilárd fázisainak, illetve fluidumkomponenseinek jellegzetes Raman-spektrumai

a) Az I. zárványtípusban megjelenő Ca-Mg-karbonát, amely mellett a jelölt spektrumon a befogadó ásvány (amfibol) Raman-sávjai is jelen vannak. b) Nitrogén ( $\mathrm{N}_{2}$ ) spektrum az I. típus zárványaiban. c) Metán $\left(\mathrm{CH}_{4}\right)$ spektrum a III. típus zárványaiban. d) Hidrohalit a II. típusú zárványokban - $190^{\circ} \mathrm{C}$-on. A karakteres Raman-sávok csak a megismételt fagyasztáskor jelentek meg. e) Szilárd $\mathrm{H}_{2} \mathrm{O}$ (vízjég) Raman-spektruma a III. zárványtípusban $-190{ }^{\circ} \mathrm{C}$-on. f) Hidrogén jellegzetes Raman-sávjai a III. zárványtípusban. g) Folyékony $\mathrm{H}_{2} \mathrm{O}$ a III. zárványtípusban

Figure 4. Characteristic Raman spectra of the solid phases and fluid components of the studied fluid inclusions

a) Ca-Mg-carbonate as the solid phase observed in Type I inclusions, whereas the spectrum of the host amphibole is also present. b) Raman spectra of nitrogen in Type I inclusions. c) Raman spectra of methane in Type III inclusions. d) Hydrohalite in Type II inclusions measured at $-190^{\circ} \mathrm{C}$. A double freezing method was applied as characteristic spectra of the salt-hydrate appeared only during the second freezing. e) Solid $\mathrm{H}_{2} \mathrm{O}$ (water ice) measured in Type III inclusions at $-190^{\circ} \mathrm{C}$. f) Raman spectra of hydrogen in Type III inclusions. $g$ ) Liquid $\mathrm{H}_{2} \mathrm{O}$ in Type III inclusions 


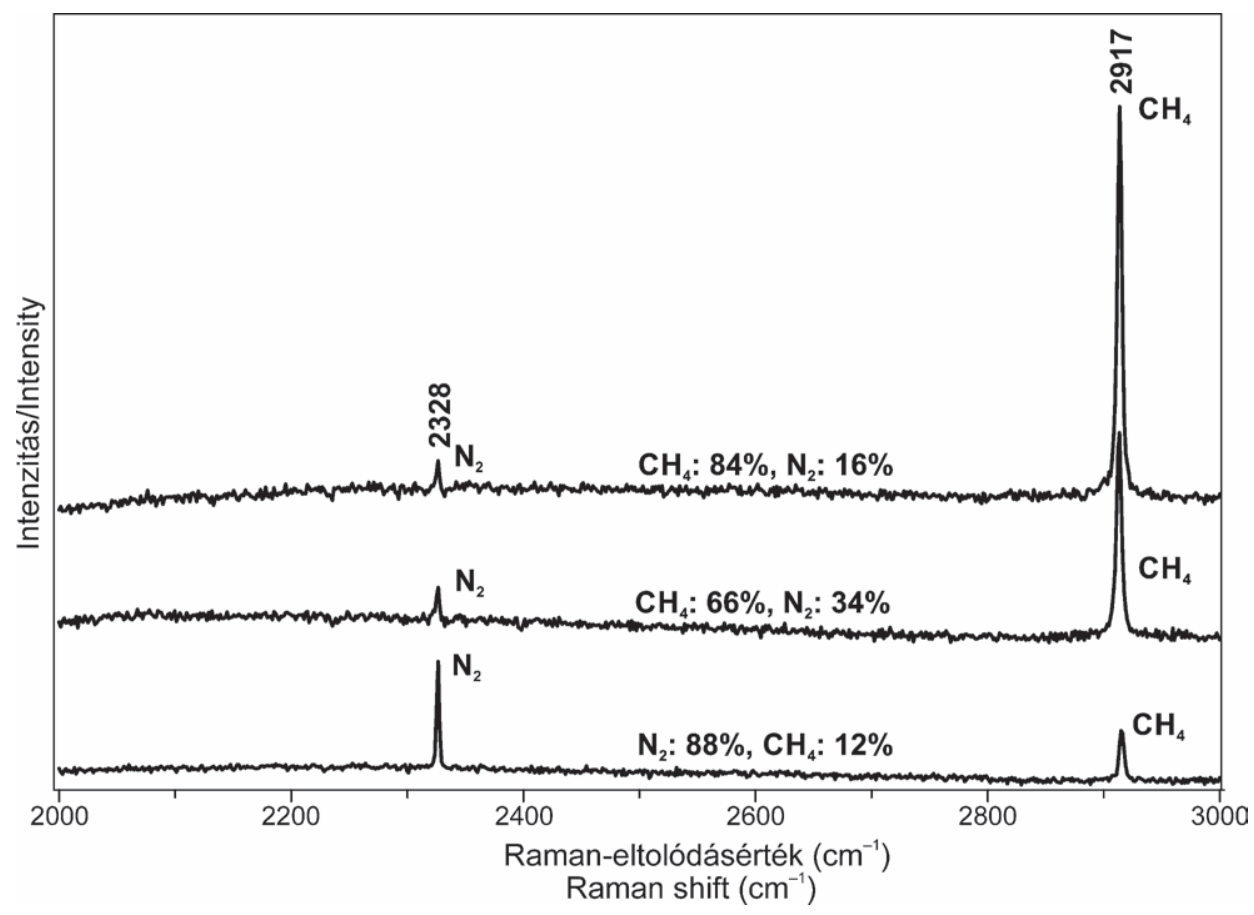

5. ábra. Az I. fluidumzárvány-típus illó komponenseinek változékonyságát mutató reprezentatív Raman-spektrumok A gázfázis minden esetben nitrogén és metán elegye, azonban ezek aránya egy beforrt repedés esetében állandó, de a különbözó repedéskitöltések között változékonyságot mutat. A két fluidum komponens Raman-sávjainak intenzitásaránya alapján mind nitrogénben, mind metánban gazdag összetétel is megfigyelhető

Figure 5. Three Raman spectra showing the variability of volatile composition in Type I inclusions

The gas phase is a mixture of nitrogen and methane showing wide range in mol percentages, however, it is consistent within a single healed fracture. According to the integrated band area of the components, both nitrogen-, and methane-rich compositions have been measured

\section{III. típusú fluidumzárványok}

A szobahőmérsékleten kétfázisú zárványok gázfázisát döntôen metán (2917 $\left.\mathrm{cm}^{-1}\right)$ alkotja, de néhány esetben a hidrogén is jelen van $\left(4128,4145,4157,4163 \mathrm{~cm}^{-1}\right)$ (4. ábra, e). Szobahőmérsékleten a folyadékfázisban a $\mathrm{H}_{2} \mathrm{O}$ Ramanspektruma azonosítható, a fagyasztásos vizsgálatok során kizárólag a $\mathrm{H}_{2} \mathrm{O}$-jég Raman-spektruma (3098, 3222 cm cm$^{-1}$ ) mutatható ki (4. ábra, $f-g$ ). A II. zárványtípusban detektált hidrohalit vagy egyéb sóhidrát szignálja nem jelenik meg. Ez a II. típusú zárványokénál kisebb sótartalomra utal.

\section{Diszkusszió}

\section{Másodlagos fluidumzárványok csapdázódása a COK piroxenitjeiben}

A COK piroxenitjeiben azonosított másodlagos fluidumzárvány-típusok a befogadó ásványok (klinopiroxén, amfibol) keletkezését követôen záródtak be, a szöveti jelleg alapján a retrográd metamorf út során (3. ábra, a, c, f). A terepi és petrográfiai sajátosságok alapján a vizsgált minták TILHAC et al. (2016) csoportosításában az ún. 3. típusnak feleltethetốk meg, melyre nagymértékú amfibolosodás jellemző, ugyanis a kőzetek retrográd fejlődésében lényeges szerepet játszhatott a deformáció és a vizes fluidumok jelenléte. Az eltérő összetételú zárványcsoportok (I., II. és III. típus) azt jelzik, hogy a vizsgált zárványok három különböző fluidumáramlási esemény anyagát csapdázták. A megfigyelt szöveti bélyegek alapján az I. és II. típusú zárványcsoportok a vizsgált kőzetekben megjelenő szerpentinerek kialakulását megelőzően, míg a III. típus azokkal egyidejúleg csapdázódhatott (3. ábra, e). A fluidumzárvány-típusok bezáródásának leginkább valószínúsíthető relatív időbeli sorrendjére a zárványok alaktani sajátosságai alapján is következtethetünk. Az I. típusú zárványok negatív kristály alakúak (3. ábra, b), tehát fejlődésük során elegendő idő állt rendelkezésre a zárvány felületi energiájának minimalizálásához és szöveti egyensúlyba kerülhettek a befogadó amfibollal (VITI \& FrezzotTi 2000, BodNAR 2003, BERKESI et al. 2012). Mindez a zárványok korai retrográd eredetére utal. Az amfibol beforrt repedései mentén előforduló I. zárványtípust létrehozó fluidum valószínúsíthetően nagy nyomáson és hőmérsékleten, a retrográd fejlődési út korai szakaszában csapdázódhatott. A II. és III. típusok zárványaira egyaránt jellemző a szabálytalan alak, azonban míg a II. típusú zárványok túlnyomórészt hosszúkásak, a III. típusban az alak nagyon változatos: szabálytalan, zegzugos, amőbaszerú (3. ábra, $d, f$ ). Ezek a zárványok (III. típus) a legelterjedtebbek, szabálytalan, zegzugos alakjuk késői eredetet jelez (a zárványok nem egyensúlyi jellege, a negatív kristály alak nem tudott kifejlődni, aminek a kis hőmérsékleten való csapdázódás kedvez). Ezek alapján mindkét csoport az I. típust követően csapdázódhatott, ezenfelül a kettő közül a III. típus a II. típust követô fázisban. Ezt erôsítheti, hogy a II. típusban a mikrotermometriai 
vizsgálatok során nagyobb homogenizációs hőmérsékletek mérhetôk, mint a III. típusban (I. táblázat), tehát nagyobb minimum csapdázódási hőmérséklet valószínúsíthető, továbbá utóbbi elterjedése a szerpentinerek mentén jellemző, tehát közvetlen képviselője lehet az ultrabázitok eredeti kőzettani és geokémiai bélyegeit felülíró szerpentinesedésnek.

\section{A csapdázódott fluidumok összetétele}

\section{I. típusú fluidumzárványok}

Az I. típusú fluidumzárványok állandó alkotóeleme szilárd fázisként a karbonát (4. ábra, a), amely a befogadó amfibolban kristályzárványként nincs jelen. Fontos megemlíteni, hogy e karbonátok a zárványokban közel azonos térfogatarányban fordulnak elő (min. 60-75\%, 3. ábra, b). Mindez kizárja a karbonát véletlenszerú (heterogén) csapdázódását, így valószínúsíthető, hogy homogén fluidumból vált ki (leányásvány) vagy a befogadó amfibollal lezajlott reakció eredményeként képződött (step-daughter phase tehát „mostohaleány-ásvány”). A karbonát (Mgtartalmú kalcit) az utóbbi folyamat során keletkezhetett a zárványokban. Ezt igazolja az amfibol Ca-ban és Mg-ban gazdag, illetve Fe-ban szegény összetétele (CaO: 12,4412,82 wt.\%, MgO: 17,50-22,55 wt.\%, FeO : 3,05-7,60 wt.\%) (TilHAC et al. 2016). Ez a csapdázódást követő fluidum-kőzet kölcsönhatási folyamat a nagy nyomású kőzetekben lévő fluidumzárványokban felismerhető, ami a zárványon belüli fizikai és kémiai változások eredményeként a hosszú exhumációs folyamat következménye is lehet (Roedder 1984, Philippot \& Selverstone 1991, Touret 2001, ScAmbelluri \& PhilipPot 2001, Bodnar 2003). A karbonát egy olyan reakció terméke, ami a befogadó ásvány és a csapdázódott fluidum között játszódik le. A kiindulási fluidum $\left(\mathrm{CO}_{2}\right)$ a reakció során felhasználódik a bezáró ásvánnyal. Ezt a folyamatot többféle befogadó ásvány esetén (plagioklász, ortopiroxén és gránát), számos tanulmány bemutatja (KLEINEFELD \& BAKKER 2002, BERKESI et al. 2012, TACCHETTO et al. 2019, ArADi et al. 2019, CARVAlho et al. 2020). Tömegegyensúlyi számítások alapján ekkor, a zárványokban jellemző karbonát térfogatarány esetén (60-75\%), egyenlő $\mathrm{N}_{2}-\mathrm{CH}_{4}$-tartalom mellett a $\mathrm{CO}_{2}$ relatív mennyisége a többi fuidum komponenshez képest min. 53,3-69,5 mol\%. Mindezek alapján az eredetileg bezárt fluidum jelentős mennyiségben tartalmazhatott $\mathrm{CO}_{2}$-ot, a $\mathrm{N}_{2}$ és $\mathrm{CH}_{4}$ mellett. A szén-dioxidot felemésztő karbonátosodási reakció eredményeként a reziduális fluidum nitrogénben és metánban gazdagodik. A metán és nitrogén relatív mennyisége egy-egy zárványsoron belül állandó, azonban a különbözô sorok között a két illókomponens aránya változó (5. ábra). A zárványsorok kialakulása ennek megfelelően egy eseménysorhoz kötődően mehetett végbe, ám az összetételi változékonyság arra utal, hogy epizodikus lehetett a fluidum be/átáramlás (POULET et al. 2014).

\section{II. és III. típusú fluidumzárványok}

A -21,2 ${ }^{\circ} \mathrm{C}$ körüli eutektikus hőmérséklet alapján a II. és III. fluidumzárvány-típusban a kémiai rendszer $\mathrm{H}_{2} \mathrm{O}-\mathrm{NaCl}$ (I. táblázat).

A II. típus zárványaiban az állandó fázisarány és a szúk tartományban változó homogenizációs hőmérsékletek alapján (270-290 ㄷ, 3. ábra, d, I. táblázat) homogén fluidum csapdázódott. Vizsgálataink alapján a zárványok $\mathrm{N}_{2}$-t és $\mathrm{CH}_{4}$-t tartalmaznak a $\mathrm{H}_{2} \mathrm{O}-\mathrm{NaCl}$ mellett (4. ábra). A zárványok nagy sótartalmát (>26,3 wt.\% NaCl, 3. ábra, $d$ ) a kôsókocka szobahőmérsékleten való jelenléte jelzi. A nitrogén, metán vagy egyéb komponensek jelenléte befolyásolja a kétkomponensú $\mathrm{H}_{2} \mathrm{O}-\mathrm{NaCl}$ rendszerre jellemzô fázisátalakulásokat (ROEDDER 1984). Mivel azonban a dekrepitációs hőmérsékleten sem oldódott be a kôsó, a sótartalom valószínúsíthetôen nagyobb, mint $~ 37$ wt.\% $\mathrm{NaCl}$ (6. ábra). Itt fontos megjegyezni, hogy a rendszerben jelen lévő $\mathrm{N}_{2}$ és $\mathrm{CH}_{4}$ ezt befolyásolhatja, tiszta $\mathrm{H}_{2} \mathrm{O}-\mathrm{NaCl}$ rendszer esetén a szalinitás felsố határa maximum 61 wt.\% $\mathrm{NaCl}$ lehet $(6$. ábra), ugyanis a fagyasztásos vizsgálatok során a hidrohaliton kívül a $\mathrm{H}_{2} \mathrm{O}$ jég Raman-spektrumát is azonosítottuk (4. ábra, d).

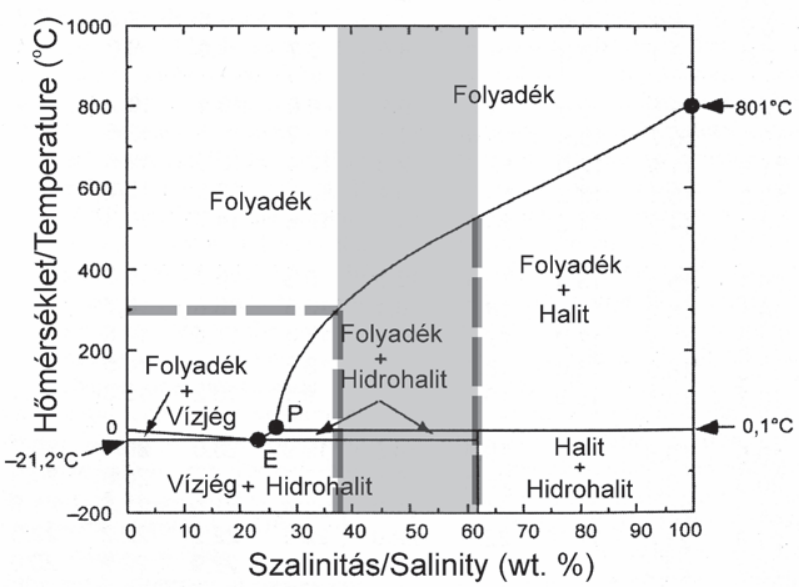

6. ábra. Szalinitás (wt.\%) vs. hőmérséklet $\left({ }^{\circ} \mathrm{C}\right)$ fázisdiagram $\left(\mathrm{H}_{2} \mathrm{O}-\mathrm{NaCl}\right.$ rendszer) a II. típusú fluidumzárványok szalinitásának becsléséhez BoDNAR (2003) alapján

Az egyes mezőkben feltüntetett fázisok mellett a fázisdiagram mindegyik mezejében feltételezett a gázfázis jelenléte. A zárványok csapdázódási sótartalmának valószinűsíthető tartománya (szürkével jelölt sáv) az alábbiak alapján jelölhető ki. A zárványokban a kősókocka szobahőmérsékleten jelen van, emellett a folyadékfázisba való homogenizációja a $300{ }^{\circ} \mathrm{C}$-os dekrepitációs hőmérsékleten még nem következett be. Fagyasztáskor ugyanakkor a $\mathrm{H}_{2} \mathrm{O}$ jég Raman-spektruma is azonosítható, tehát a szalinitás valószínűsíthetően 37-61 wt.\% $\mathrm{NaCl}$ (szürkével jelölt sáv). $\mathrm{E}$ - eutektikus hőmérséklet: $\left(-21,2{ }^{\circ} \mathrm{C}\right.$, $23,2$ wt.\% $\mathrm{NaCl}), \mathrm{P}$ - peritektikus hỏmérséklet $\left(0,1^{\circ} \mathrm{C}, 26,3 \mathrm{wt} . \% \mathrm{NaCl}\right)$. Ez a tartomány azonban csak tiszta $\mathrm{H}_{2} \mathrm{O}-\mathrm{NaCl}$ rendszer esetén jelölhető ki bizonyossággal, a jelen lévő $\mathrm{N}_{2}$ és $\mathrm{CH}_{4}$ befolyásolhatja a fázisátalakulások szabályait (ROEDDER 1984)

Figure 6. Salinity (wt.\%) vs. temperature $\left({ }^{\circ} \mathrm{C}\right)$ phase diagram in the vapor saturated $\mathrm{H}_{2} \mathrm{O}-\mathrm{NaCl}$ system presenting the phase topology and the possible range of salinity entrapped in Type II fluid inclusions based on BODNAR (2003)

The area marked in grey is constructed due to the followings. At room temperature salt cube is present and its homogenization to the liquid phase did not occur at $300{ }^{\circ} \mathrm{C}$, however the inclusions were decrepitated at this temperature. Furthermore, at $-190^{\circ} \mathrm{C}$ the spectra of water ice was detected as well, therefore estimated salinity is 37-61 wt\% NaCl. E-eutectic temperature: $\left(-21,2^{\circ} \mathrm{C}, 23,2 \mathrm{wt} . \% \mathrm{NaCl}\right), \mathrm{P}$ - peritectic temperature $\left(0,1^{\circ} \mathrm{C}, 26,3 \mathrm{wt} . \% \mathrm{NaCl}\right)$. Note, that the indicated area is an approximation here, due to the presence of $\mathrm{N}_{2}$ and $\mathrm{CH}_{4}$ influencing the behavior of phase changes in the $\mathrm{H}_{2} \mathrm{O}-\mathrm{NaCl}$ system (ROEDDER 1984) 
A III. típusú zárványokban metángazdag, esetenként hidrogéntartalmú vizes fluidum csapdázódott, a zárványsorok közvetlenül a szerpentinerekhez kötődnek (3. ábra, e). A -5,0 és $-1,4^{\circ} \mathrm{C}$ közötti végső olvadási hőmérsékletek (I. táblázat) alapján számolható szalinitás: 2,4-7,9wt.\% $\mathrm{NaCl}$ (BoDNAR 1993). A kriogén Raman-spektroszkópiai vizsgálat $-190{ }^{\circ} \mathrm{C}$-on sóhidrátot nem mutatott ki (4. ábra, e), ami megerôsíti, hogy a fluidum kisebb sótartalmú $(\mathrm{NaCl})$ víz, mint a II. típus esetén. 9 wt. \% NaCl alatti szalinitásnál ugyanis fagyasztás során a hidrohalit Raman-spektruma alig vagy nem jelenik meg (Ni et al. 2006).

\section{A retrográd fluidumok eredete és szerepe a szubdukciós zónában}

Az ultrabázisos kőzetek, a nyírásos zónák mentén kialakult amfibolit és zöldpala fáciesû retrográd felülbélyegzések mellett jelentős szerpentinesedést is szenvedtek az exhumáció során (GIL IBARGUCHI et al. 1999, ÁBALOS et al. 2003). Ez utóbbi, valamint a három másodlagos fluidumzárvány-generáció jelzi, hogy a COK metamorf fejlődésének retrográd szakaszában nagy szerepet játszott a különböző összetételú fluidumok beáramlása és a kőzettel való kölcsönhatása (PEREIRA et al. 2008, TilHAC et al. 2016).
A másodlagos fluidumzárványok vizsgálata alapján három eltérô összetételű fluidummigrációs eseményt különíthetünk el, időben feltételezhetôen az alábbi sorrendben: 1) $\mathrm{CO}_{2}$-gazdag és $\mathrm{N}_{2}-\mathrm{CH}_{4}$-tartalmú fluidum, 2) $\mathrm{N}_{2}-\mathrm{CH}_{4}$ tartalmú, nagy sótartalmú vizes fluidum, 3) $\mathrm{CH}_{4}$-gazdag, alárendelten $\mathrm{H}_{2}$-tartalmú, enyhén sós fluidum (7. ábra).

A szubdukciós környezetben jelen lévő fluidumok jelentős alkotórészei a C-O-H-N-S erôsen inkompatibilis elemek és a tengervíznél nagyobb sótartalmú fluidumok (brine-ok) (FrEZzOTTI \& FERRANDo 2015).

Az I. típusú fluidumzárványok összetétele alapján valószínúsíthető, hogy azok nagyfokú metamorf környezetből erednek, tekintve, hogy a $\mathrm{CO}_{2}-$ mint e típus fö komponense - nagy hőmérsékletú (granulitok) és nagy nyomású (eklogit) környezetben általános(RoEDDER 1984, ANDERSEN et al. 1989, HAll \& BoDNAR 1990, KLEMD et al. 1992, SCAMBelluri \& Philippot 2001, FrezzotTi \& Ferrando 2015). A retrográd út korai szakaszában történt csapdázódás lehetőségét erősíti továbbá a szöveti egyensúly kialakulását jelzô negatív kristály alak. A C-tartalmú fluidumok $\left(\mathrm{CO}_{2}\right.$ és $\mathrm{CH}_{4}$ ) elsődleges forrása a szubdukciós zónába kerülő karbonátok és szerves anyag (TAO et al. 2018). A zárványokban csapdázódott fluidum $\mathrm{CO}_{2}-\mathrm{CH}_{4}$ aránya, a szénben telített COH fluidum kémiai formája (speciációja) és stabilitása az

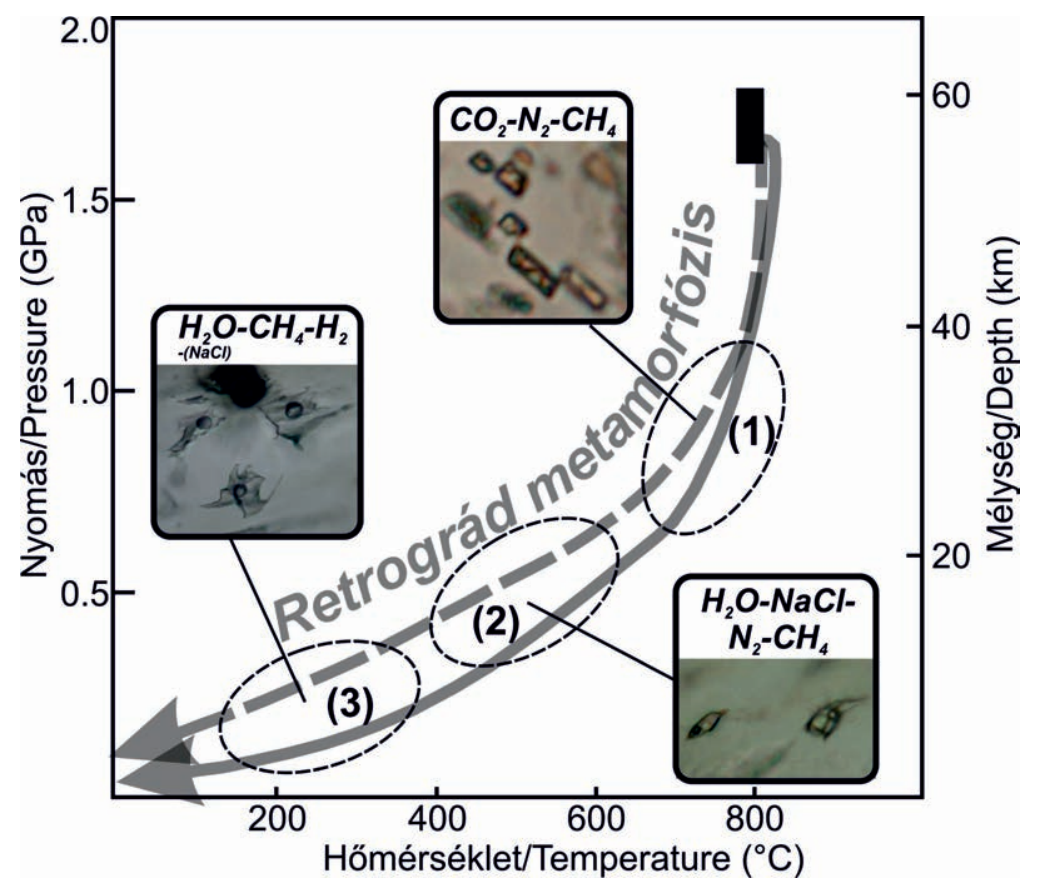

7. ábra. A COK ultrabázisos egységének retrográd metamorf P-T útja során jellemző fluidum migrációs események relatív sorrendje és kemizmusa a vizsgált másodlagos fluidumzárványtípusok alapján

A hasonló retrográd utat jelző P-T görbék a COK ultramafikus egység exhumációjára vonatkoznak (szaggatott vonallal jelzett görbe: ORDÓŃEZ CASADO et al. (2001) után, összefüggő vonallal jelzett görbe: PuELLES et al. (2012) után). A csúcsmetamorfózis tartománya (1,6-1,8 GPa, 780-800 ${ }^{\circ} \mathrm{C}$ ) TILHAC et al. (2016) munkája alapján van jelölve

Figure 7. Tentative retrograde metamorphic evolution of ultramafics of the COC with respect to the relative chronology and chemistry of fluid migration events based on the studied secondary fluid inclusion types

P-T paths of ultramafic rocks of the COC were drawn according to ORDÓNÉZ CASADO et al. (2001) (curve with a dashed line) and PUELLES et al. (2012) (curve with a continuous line), whereas peak metamorphic conditions (black rectangle: $1.6-1.8 \mathrm{GPa}, 780-800^{\circ} \mathrm{C}$ ) are indicated as determined by TILHAC et al. (2016) 
adott nagy nyomású és nagy hőmérsékletú környezet oxigénfugacitása szerint változhat (HALL \& BODNAR 1990, Connolly 1995, CAnNaó \& Malaspina 2018, Tumiati \& Malaspina 2019). Nagy nyomáson, a karbonátok redukciója során $\mathrm{H}_{2} \mathrm{O}$ jelenlétében abiogén metán képződhet, amely komponenseket eklogit-granulit fáciesú kôzetek metamorf fluidumaiban több esetben kimutatták (Fu et al. 2003, Mukherjee \& Sachan 2009, Tao et al. 2018). A retrográd metamorf úton csapdázódott fluidumzárványokban gyakori $\mathrm{CH}_{4}-\mathrm{CO}_{2}-\mathrm{N}_{2}$ fluidumok arányának változékonyságát az akár mm-cm-es léptékben is változó oxigénfugacitás indokolhatja (VAN DEN KERKHOFF et al. 1991).

A szubdukált kőzetekben csapdázódott fluidumzárványok tanúsága alapján az $\mathrm{N}_{2}$ a legelterjedtebb apoláris molekula a szubdukcióhoz kötődő nagy nyomású metamorfózis során (TOURET 2001, FrEzZOTTI \& FERRANDO 2015). A szubdukciós zónában jelen lévő nitrogén forrása az óceánaljzatra lerakódott szerves anyag, amely N-tartalmának egy része reduktív környezetben $\mathrm{NH}_{4}^{+}$ionként a progresszív metamorfózis során a $\mathrm{K}^{+}$-t helyettesítve elsődlegesen a rétegszilikátok (agyagásványok, csillámok) szerkezetébe épül be (ANDERSEN et al. 1991, BUSIGNY et al. 2003, BEBOUT et al. 2013a, b, Busigny \& BeBout 2013). A szubdukció előrehaladásával bekövetkezô metamorf devolatilizációs reakciók során (főképp a zöldpala fáciesen jellemző és annál nagyobb hőmérsékleten) a csillámok átalakulásával $\mathrm{NH}_{4}^{+}$szabadul fel, amely oxidatív viszonyok között a fluidum fázisban $\mathrm{N}_{2}$ formájában stabilizálódhat (BusigNY \& Bebout 2013). Ezért a szubdukciós csatornában a nitrogén a progresszív és csúcsmetamorf fluidumok mellett a retrográd fluidumokban is gyakori komponens, amit elsődleges és másodlagos fluidumzárványok $\mathrm{N}_{2}$-gazdagsága igazol (ANDERSEN et al. 1989, 1993).

Az óceáni litoszféralemez alábukása során a nyomás és hőmérséklet növekedésével az illótartalmú elegyrészek (szerves anyag, agyagásvány, karbonát, szulfid, csillám, amfibol) stabilitási zónájának folyamatos átlépésével nagy mennyiségú fluidum szabadul fel. A szubdukciós fluidumokban a $\mathrm{H}_{2} \mathrm{O}$ általános jelenlétét az okozza, hogy ez szabadul fel a legnagyobb mennyiségben egyéb illó komponensekhez képest (pl. $\mathrm{CO}_{2}, \mathrm{~N}_{2}$ ) (MANNING 2004). A nagy és ultranagy nyomáson csapdázódott, szuperkritikus állapotú $\mathrm{H}_{2} \mathrm{O}$ és $\mathrm{CO}_{2}$ azonban a fluidumzárványokban csak nagyon ritkán őrződik meg, ugyanis a hosszú exhumációs folyamatok során törések / repedések / hasadási síkok mentén és/vagy diffúzióval mobilizálódik, vagy reakcióba lép a befogadó ásvánnyal, mostohaleány-ásványt (víztartalmú szilikátokat, karbonátokat) képezve (SCAMBELLURI \& PHILippot 2001, FrezzotTi \& FERRANDo 2015, Ni et al. 2017, CARvalho et al. 2020).

A retrográd fluidumok további lényeges komponense a sós víz (II. és III. típus), amelynek jelenléte módosult tengervíz eredethez (szubdukciós folyamatok során újracirkulált) köthető, hasonlóan a norvég Kaledonidák és az ománi Saih Hatat eklogit fáciesû kôzeteiben azonosított fluidumzárványokkal (ANDERSEN et al. 1989, 1993; SCAMBELLURI et al. 1997; El-SHAZLY \& SiSSON 1999). A szöveti bizonyítékok igazolják, hogy a III. típusú $\mathrm{CH}_{4}$-gazdag, alárendelten $\mathrm{H}_{2}$-tartalmú enyhén sós $(2,41-7,86$ wt.\% $\mathrm{NaCl})$ fluidumzárványokként csapdázódva a szerpentinesedéshez kötődik (3. ábra, e), amely a vizsgált kőzetekben a legelterjedtebb és a legkésőbbi, az egész kőzettani egységet átható szerpentinesedésért felelős fluidumként értelmezhető. A szerpentinesedett ultrabázisos kôzetek esetén számos területrôl ismert, hogy metánban és hidrogénben gazdag \pm sós vizes fluidumzárványokat tartalmaznak (Fu et al. 2003, SACHAN et al. 2007, KLEIN et al. 2019). Tengeraljzati, köpenyék és mélyebb szubdukciós környezetben egyaránt jellemzó, hogy az olivinben gazdag ultrabázisos kőzetek szerpentinesedése során - reduktív környezetben - metánban és hidrogénben gazdag vizes fluidumok szabadulnak fel (GreEN et al. 1987, Fu et al. 2003, Brovarone et al. 2017, KLEIN et al. 2019). A természetes képződményekben azonosított szerpentinesedésért felelős fluidum jellegzetes összetételét termodinamikai modellezéssel és kísérleti módszerekkel is igazolták (MCCOLLOM 2016, KLEIN et al. 2019, Brovarone et al. 2020) A szerpentinesedés egy olyan retrográd reakció, amelynek során nagy mennyiségú abiogén hidrogén és metán kerül a légkörbe. Ennek döntő mennyisége a Föld óceánközépi hátságainál szabadul fel $\left(\mathrm{H}_{2}\right.$ : 0,02-1,4 megatonna/év, $\mathrm{CH}_{4}$ : 1,1-1,9 megatonna/év mindösszesen), amelyhez jelentős mennyiséggel járulhat hozzá a szubdukciós zónában sekély és nagy nyomáson zajló szerpentinesedés is (MERDITH et al. 2020, BROVARONE et al. 2020).

\section{Következtetések}

A COK ultrabázisos egységének piroxenitjeiben olyan fluidumzárványokat különítettünk el, melyek a kőzet csúcsmetamorfózisát követően, a szubdukciós csatornafolyamatok során, a retrográd úton csapdázódhattak. A Herbeira- és Limo-masszívum amfiboltartalmú piroxenit kőzeteiben több másodlagos fluidumzárvány-típust azonosítottunk. Az amfibol és klinopiroxén beforrt repedései mentén megjelenő zárványok három, eltérő összetételú fluidummigrációs eseményt jeleznek, időben az alábbi sorrendben: 1) $\mathrm{CO}_{2}-\mathrm{N}_{2}-\mathrm{CH}_{4}$ fluidum, 2) nagy szalinitású (37-61 wt.\% $\mathrm{NaCl}) \mathrm{N}_{2}-\mathrm{CH}_{4}-\mathrm{NaCl}-\mathrm{H}_{2} \mathrm{O}$ fluidum, 3) kisebb szalinitású $(2,41-7,86$ wt.\% $\mathrm{NaCl}) \mathrm{CH}_{4}-\mathrm{H}_{2}-\mathrm{H}_{2} \mathrm{O}-\mathrm{NaCl}$ fluidum. A legkorábban bezáródott zárványokban a csapdázódást követően karbonátosodási reakció mehetett végbe, melynek alapján a kiindulási fluidum $\mathrm{CO}_{2}$-ban gazdag volt (min. 53,3-69,5 mol\%). A zárványok reziduális fluidumfázisában lévő $\mathrm{N}_{2}$ forrása a szubdukálódott szervesanyag-tartalmú üledék lehetett, míg a NaCl- $\mathrm{H}_{2} \mathrm{O}$ fluidumok eredete módosult, a szubdukciós folyamatok során újracirkulált tengervízként értelmezhetô. A legfiatalabb fluidumáramlási esemény az ultrabázisos kőzetek szerpentinesedéséhez köthetô, melynek közvetlen bizonyítékai a $\mathrm{CH}_{4}$-ben és $\mathrm{H}_{2}$-ben gazdag, enyhén sós vizes fluidumzárványok. Az ultrabázisos kőzetek ásványaiban csapdázódott másodlagos fluidumzárványok vizsgálatával a retrográd metamorf fejlődés 
során áramló fluidum kemizmusa és az anyakôzettel való kölcsönhatása válik megismerhetővé.

\section{Köszönetnyilvánítás}

Köszönetet szeretnénk mondani ARADI Lászlónak a Raman-spektroszkópos vizsgálatok során nyújtott segítségéért. A szerzők köszönettel tartoznak SzTANó Orsolya főszerkesztői munkájáért, illetve SCHUBERT Félixnek és egy anonim bírálónak és a kézirat bírálata során tett konstruktív javaslatokért és javításokért. Köszönjük továbbá az ELTE Központi Kutató és Ipari Kapcsolatok Centrumának támogatását. A kutatómunka az Innovációs és Technológiai Minisztérium ÚNKP-19-3 kódszámú Új Nemzeti Kiválóság Programjának szakmai támogatásával készült (pályázati azonosító: ÚNKP-19-3-I-ELTE-604). A tanulmány a Litoszféra Fluidum Kutató Laboratórium 106. publikációja.

\section{Irodalom - References}

Ábalos, B., Puelles, P. \& Gil Ibarguchi, J. I. 2003: Structural assemblage of high pressure mantle and crustal rocks in a subduction channel (Cabo Ortegal, NW Spain). - Tectonics 22/2, https://doi.org/10.1029/2002tc001405

Ábalos, B., Fountain, D. M., Gil Ibarguchi, J. I. \& Puelles, P. 2011: Eclogite as a seismic marker in subduction channels: Seismic velocities, anisotropy, and petrofabric of Cabo Ortegal eclogite tectonites (Spain). - Geological Society of America Bulletin 123/34, 439-456. https://doi.org/10.1130/b30226.1

Albert, R., Arenas, R., Gerdes, A., Martínez, S. S., FernándeZ-Suárez, J. \& Fuenlabrada, J. M. 2015: Provenance of the Variscan Upper Allochthon (Cabo Ortegal Complex, NW Iberian Massif). - Gondwana Research 28/4, 1434-1448. https://doi.org/10.1016/ j.gr.2014.10.016

Andersen, T., Burke, E. A. J. \& Austrheim, H. 1989: Nitrogen-bearing, aqueous fluid inclusions in some eclogites from the Western Gneiss Region of the Norwegian Caledonides. - Contributions to Mineralogy and Petrology 103/2, 153-165. https://doi.org/10.1007/ bf00378501

Andersen, T., Austrheim, H. \& Burke, E. A. J. 1991: Fluid-induced retrogression of granulites in the Bergen Arcs, Caledonides of W. Norway: Fluid inclusion evidence from amphibolite-facies shear zones. - Lithos 27/1, 29-42. https://doi.org/10.1016/00244937(91)90018-g

Andersen, T., Austrheim, H., Burke, E. A. \& Elvevold, S. 1993: $\mathrm{N}_{2}$ and $\mathrm{CO}_{2}$ in deep crustal fluids: evidence from the Caledonides of Norway. - Chemical Geology 108/1-4, 113-132. https://doi.org/10.1016/0009-2541(93)90320-i

ARADI L. E., BERKESI M. \& SZABÓ Cs. 2019: Felsőköpeny fluidumok összetétele és eredete fluidumzárvány-vizsgálatok alapján a Stájermedence amfibolgazdag harzburgit xenolitjában. - Földtani Közlöny 149/1, 35-49. https://doi.org/10.23928/foldt.kozl.2019.149.1.35

BAUMgartner, M. \& BAKKeR, R. J. 2010: Raman spectra of ice and salt hydrates in synthetic fluid inclusions. - Chemical Geology 275/1-2, 58-66. https://doi.org/10.1016/j.chemgeo.2010.04.014

Bebout, G. E., Agard, P., Kobayashi, K., Moriguti, T. \& Nakamura, E. 2013a: Devolatilization history and trace element mobility in deeply subducted sedimentary rocks: Evidence from Western Alps HP/UHP suites. - Chemical Geology 342, 1-20. https://doi.org/ 10.1016/j.chemgeo.2013.01.009

Bebout, G. E., Fogel, M. L. \& Cartigny, P. 2013b: Nitrogen: Highly volatile yet surprisingly compatible. - Elements 9/5, $333-338$. https://doi.org/10.2113/gselements.9.5.333

Berkesi, M., Guzmics, T., Szabó, Cs., Dubessy, J., Bodnar, R. J., Hidas, K. \& RatTer, K. 2012: The role of $\mathrm{CO}_{2}$-rich fluids in trace element transport and metasomatism in the lithospheric mantle beneath the Central Pannonian Basin, Hungary, based on fluid inclusions in mantle xenoliths. - Earth and Planetary Science Letters 331, 8-20. https://doi.org/10.1016/j.epsl.2012.03.012

Bischoff, W. D., Sharma, S. K. \& MACKenZIE, F. T. 1985: Carbonate ion disorder in synthetic and biogenic magnesian calcites: a Raman spectral study. - American Mineralogist 70/5-6, 581-589.

BoDNAR, R. J. 1993: Revised equation and table for determining the freezing point depression of $\mathrm{H}_{2} \mathrm{O}-\mathrm{NaCl}$ solutions. - Geochimica et Cosmochimica Acta 57(3), 683-684. https://doi.org/10.1016/0016-7037(93)90378-a

BodnAR, R. J. 2003: Interpretation of data from aqueous electrolyte fluid inclusions. - In: SAMSOn, I. M., ANDERSON, A. J. \& MARSHALL, D. (eds): Fluid Inclusions; Analysis and Interpretation - Mineralogical Association of Canada Short Course Series 32, 81-100,

Borromeo, L., Zimmermann, U., AndÑ, S., Coletti, G., Bersani, D., Basso, D., Gentile, S., Schulz, B. \& Garzanti, E. 2017: Raman spectroscopy as a tool for magnesium estimation in Mg-calcite. - Journal of Raman Spectroscopy 48/7, 983-992. https://doi.org/ 10.1002/jrs.5156

Brovarone, A. V., Martinez, I., Elmaleh, A., Compagnoni, R., Chaduteau, C., Ferraris, C. \& Esteve, I. 2017: Massive production of abiotic methane during subduction evidenced in metamorphosed ophicarbonates from the Italian Alps. - Nature Communications 8/1, 1-13. https://doi.org/10.1038/ncomms14134

Brovarone, A. V., Sverjensky, D. A., Piccoli, F., Ressico, F., Giovannelli, D. \& Daniel, I. 2020: Subduction hides high-pressure sources of energy that may feed the deep subsurface biosphere. - Nature Communications 11/1, 1-11. https://doi.org/10.1038/s41467$020-17342-\mathrm{X}$

BusignY, A. V. \& Bebout, G. E. 2013: Nitrogen in the silicate Earth: Speciation and isotopic behavior during mineral-fluid interactions. - Elements 9/5, 353-358. https://doi.org/10.2113/gselements.9.5.353 
Busigny, V., CARtigny, P., Philippot, P., Ader, M. \& Javoy, M. 2003: Massive recycling of nitrogen and other fluid-mobile elements (K, $\mathrm{Rb}, \mathrm{Cs}, \mathrm{H}$ ) in a cold slab environment: evidence from HP to UHP oceanic metasediments of the Schistes Lustrés nappe (western Alps, Europe). - Earth and Planetary Science Letters 215/1-2, 27-42. https://doi.org/10.1016/s0012-821x(03)00453-9

CANNAÑ , E. \& Malaspina, N. 2018: From oceanic to continental subduction: Implications for the geochemical and redox evolution of the supra-subduction mantle. - Geosphere 14/6, 2311-2336. https://doi.org/10.1130/ges01597.1

Carvalho, B. B., Bartoli, O., Cesare, B., Tacchetto, T., Gianola, O., Ferri, F., Aradi, L. E. \& Szabó, Cs. 2020: Primary CO ${ }_{2}$-bearing fluid inclusions in granulitic garnet usually do not survive. - Earth and Planetary Science Letters 536, 116170. https://doi.org/ 10.1016/j.epsl.2020.116170

Connolly, J. A. D. 1995: Phase diagram methods for graphitic rocks and application to the system C-O-H-FeO-TiO $-\mathrm{SiO}_{2}-\mathrm{Contri}_{-}$ butions to Mineralogy and Petrology 119/1, 94-116. https://doi.org/10.1007/bf00310720

Dubessy, J., Poty, B. \& RAMBOZ, C. 1989: Advances in COHNS fluid geochemistry based on micro-Raman spectrometric analysis of fluid inclusions. - European Journal of Mineralogy 1/4, 517-534. https://doi.org/10.1127/ejm/1/4/0517

El-ShazLY, A. K. \& Sisson, V. B. 1999: Retrograde evolution of eclogite facies rocks from NE Oman: evidence from fluid inclusions and petrological data. - Chemical Geology 154/1-4, 193-223. https://doi.org/10.1016/s0009-2541(98)00132-6

FrezzotTi, M. L. \& FerRANDO, S. 2015: The chemical behavior of fluids released during deep subduction based on fluid inclusions. American Mineralogist 100/2-3, 352-377. https://doi.org/10.2138/am-2015-4933

Frezzotti, M. L., Tecce, F. \& CASAGLI, A. 2012: Raman spectroscopy for fluid inclusion analysis. - Journal of Geochemical Exploration 112, 1-20. https://doi.org/10.1016/j.gexplo.2011.09.009

Fu, B., Touret, J. L. R. \& ZhenG, Y. F. 2003: Remnants of premetamorphic fluid and oxygen isotopic signatures in eclogites and garnet clinopyroxenite from the Dabie-Sulu terranes, eastern China. - Journal of Metamorphic Geology 21/6, 561-578. https://doi.org/ 10.1046/j.1525-1314.2003.00464.x

Gil Ibarguchi, J. I., Mendia, M., Girardeau, J. \& Peucat, J. J. 1990: Petrology of eclogites and clinopyroxene-garnet metabasites from the Cabo Ortegal Complex (northwestern Spain). - Lithos 25/1-3, 133-162. https://doi.org/10.1016/0024-4937(90)90011-o

Gil Ibarguchi, J. I., Ábalos, B., Azcarraga, J. \& Puelles, P. 1999: Deformation, high pressure metamorphism and exhumation of ultramafic rocks in a deep subduction/collision setting (Cabo Ortegal, NW Spain). - Journal of Metamorphic Geology 17/6, 747-764. https://doi.org/10.1046/j.1525-1314.1999.00227.x

Girardeau, J. \& Gil Ibarguchi, J. I. 1991: Pyroxenite-rich peridotites of the Cabo Ortegal complex (Northwestern Spain): evidence for large-scale upper-mantle heterogeneity. - Journal of Petrology 2, 135-154. https://doi.org/10.1093/petrology/special_ volume.2.135

Green, D. H., FALloOn, T. J. \& TAYLOR, W. R. 1987: Mantle-derived magmas-roles of variable source peridotite and variable CHO fluid compositions. - In: Mysen, B. O. (ed.): Magmatic Processes: Physicochemical Principles. Geochemical Society, Pennsylvania State University, Special Publication I. 1987

Hall, D. L. \& Bodnar, R. J. 1990: Methane in fluid inclusions from granulites: A product of hydrogen diffusion? - Geochimica et Cosmochimica Acta 54/3, 641-651. https://doi.org/10.1016/0016-7037(90)90360-w

Henry, H., Tilhac, R., Griffin, W. L., O’Reilly, S. Y., Satsukawa, T., Kaczmarek, M. A., Grégoire, M. \& Ceuleneer, G. 2017: Deformation of mantle pyroxenites provides clues to geodynamic processes in subduction zones: Case study of the Cabo Ortegal Complex, Spain. - Earth and Planetary Science Letters 472, 174-185. https://doi.org/10.1016/j.eps1.2017.05.028

Klein, F., Grozeva, N. G. \& SeEwald, J. S. 2019: Abiotic methane synthesis and serpentinization in olivine-hosted fluid inclusions. Proceedings of the National Academy of Sciences 116/36, 17666-17672. https://doi.org/10.1073/pnas.1907871116

KLEINEFELD, B. \& BAKKER, R. J. 2002: Fluid inclusions as microchemical systems: evidence and modelling of fluid-host interactions in plagioclase. - Journal of Metamorphic Geology 20/9, 845-858. https://doi.org/10.1046/j.1525-1314.2002.00411.x

KlemD, R., VAn DEN KerKHof, A. M. \& HoRn, E. E. 1992: High-density $\mathrm{CO}_{2}-\mathrm{N}_{2}$ inclusions in eclogite-facies metasediments of the Münchberg gneiss complex, SE Germany. - Contributions to Mineralogy and Petrology 111/3, 409-419. https://doi.org/10.1007/ bf00311200

Lafuente, B, Downs, R. T., YAnG, H. \& Stone, N. 2015: The power of databases: the RRUFF project. In: ARmbruster, T. \& DANISI, R. M. (eds): Highlights in Mineralogical Crystallography. Berlin, Germany, W. De Gruyter, 1-30 https://doi.org/10.1515/ 9783110417104-003

ManNING, C. E. 2004: The chemistry of subduction-zone fluids. - Earth and Planetary Science Letters 223/1-2, 1-16. https://doi.org/ 10.1016/j.eps1.2004.04.030

Martínez Catalán, J. R., Aller, J., Alonso, J. L. \& Bastida, F. 2009. The Iberian Variscan orogen. - In: García-Cortés, Á. (ed.): Spanish Geological Frameworks and Geosites: an approach to Spanish geological heritage of international relevance. IGME, 13-27.

Marcos, A., Farias, P., Galán, G., Fernández, F. J. \& Llana-Fúnez, S. 2002: Tectonic framework of the Cabo Ortegal Complex: A slab of lower crust exhumed in the Variscan orogen (northwestern Iberian Peninsula). - Special Papers of the Geological Society of America, 143-162. https://doi.org/10.1130/0-8137-2364-7.143

McCollom, T. M. 2016: Abiotic methane formation during experimental serpentinization of olivine. - Proceedings of the National Academy of Sciences 113/49, 13965-13970. https://doi.org/10.1073/pnas.1611843113

Merdith, A. S., Del Real, P. G., Daniel, I., Andreani, M., Wright, N. M. \& Coltice, N. 2020: Pulsated Global Hydrogen and Methane Flux at Mid-Ocean Ridges Driven by Pangea Breakup. - Geochemistry, Geophysics, Geosystems 21/4, e2019GC008869. https://doi.org/10.1029/2019gc008869

MukherJeE, B. K. \& SACHAN, H. K. 2009: Fluids in coesite-bearing rocks of the Tso Morari Complex, NW Himalaya: evidence for entrapment during peak metamorphism and subsequent uplift. - Geological Magazine 146/6, 876-889. https://doi.org/10.1017/ s0016756809990069 
Ni, H., Zhang, L., Xiong, X., MaO, Z. \& WANG, J. 2017: Supercritical fluids at subduction zones: Evidence, formation condition, and physicochemical properties. - Earth-Science Reviews 167, 62-71. https://doi.org/10.1016/j.earscirev.2017.02.006

Ordóñez Casado, B. O., Gebauer, D., SchäFer, H. J., Gil Ibarguchi, J. I. \& Peucat, J. J. 2001: A single Devonian subduction event for the HP/HT metamorphism of the Cabo Ortegal complex within the Iberian Massif. - Tectonophysics 332/3, 359-385. https://doi.org/ 10.1016/s0040-1951(00)00210-9

Pereira, M. D., Peinado, M., Blanco, J. A. \& Yenes, M. 2008: Geochemical characterization of serpentinites at Cabo Ortegal, northwestern Spain. - The Canadian Mineralogist 46/2,317-327. https://doi.org/10.3749/canmin.46.2.317

Philippot, P. \& Selverstone, J. 1991: Trace-element-rich brines in eclogitic veins: implications for fluid composition and transport during subduction. - Contributions to Mineralogy and Petrology 106/4, 417-430. https://doi.org/10.1007/bf00321985

Poulet, T., Veveakis, M., Herwegh, M., Buckingham, T. \& Regenauer Lieb, K. 2014: Modeling episodic fluid-release events in the ductile carbonates of the Glarus thrust. - Geophysical Research Letters 41/20, 7121-7128. https://doi.org/10.1002/2014gl061715

Puelles, P., Ábalos, B. \& Gil Ibarguchi, J. I. 2005: Metamorphic evolution and thermobaric structure of the subduction-related Bacariza high-pressure granulite formation (Cabo Ortegal Complex, NW Spain). - Lithos 84/1-2, 125-149. https://doi.org/10.1016/ j.lithos.2005.01.009

Puelles, P., ÁBALOS, B. \& GIL IBARGUChI, J. I. 2009: Transposed high-pressure granulite fabrics (Cabo Ortegal, NW Spain): Implications on the scales of deformation localization. - Journal of Structural Geology 31/8, 776-790. https://doi.org/10.1016/j.jsg.2009.05.001

RoEDDER, E. 1984: Fluid inclusions. - Reviews in Mineralogy 12. Mineralogical Society of America, 644 p. https://doi.org/ $10.1515 / 9781501508271$

SAChAn, H. K., MukherJee, B. K. \& Bodnar, R. J. 2007: Preservation of methane generated during serpentinization of upper mantle rocks: Evidence from fluid inclusions in the Nidar ophiolite, Indus Suture Zone, Ladakh (India). - Earth and Planetary Science Letters 257/1-2, 47-59. https://doi.org/10.1016/j.eps1.2007.02.023

SANTOS, J. F., Schärer, U., Gil IbARGUChI, J. I. \& GirardeAU, J. 2002: Genesis of pyroxenite-rich peridotite at Cabo Ortegal (NW Spain): geochemical and $\mathrm{Pb}-\mathrm{Sr}-\mathrm{Nd}$ isotope data. - Journal of Petrology 43/1, 17-43. https://doi.org/10.1093/petrology/43.1.17

SCAmbelluRi, M. \& Philippot, P. 2001: Deep fluids in subduction zones. - Lithos 55/1-4, 213-227. https://doi.org/10.1016/s00244937(00)00046-3

Tacchetto, T., Bartoli, O., Cesare, B., Berkesi, M., Aradi, L. E., Dumond, G. \& Szabó, Cs. 2019: Multiphase inclusions in peritectic garnet from granulites of the Athabasca granulite terrane (Canada): Evidence of carbon recycling during Neoarchean crustal melting. - Chemical Geology 508, 197-209. https://doi.org/10.1016/j.chemgeo.2018.05.043

TaO, R., Zhang, L., Tian, M., Zhu, J., Liu, X., LiU, J., HöFer, H. E., Stagno, V. \& Fei, Y. 2018: Formation of abiotic hydrocarbon from reduction of carbonate in subduction zones: Constraints from petrological observation and experimental simulation. - Geochimica et Cosmochimica Acta 239, 390-408. https://doi.org/10.1016/j.gca.2018.08.008

Tilhac, R., Ceuleneer, G., Griffin, W. L., O’Reilly, S. Y., Pearson, N. J., Benoit, M., Henry, H., Girardeau, J. \& GréGoire, M. 2016 : Primitive arc magmatism and delamination: petrology and geochemistry of pyroxenites from the Cabo Ortegal Complex, Spain. Journal of Petrology 57/10, 1921-1954. https://doi.org/10.1093/petrology/egw064

Tilhac, R., Grégoire, M., O’Reilly, S. Y., Griffin, W. L., Henry, H. \& Ceuleneer, G. 2017: Sources and timing of pyroxenite formation in the sub-arc mantle: Case study of the Cabo Ortegal Complex, Spain. - Earth and Planetary Science Letters 474, 490-502. https://doi.org/10.1016/j.eps1.2017.07.017

Tilhac, R., Oliveira, B., Griffin, W. L., O’Reilly, S. Y., Schaefer, B. F., Alard, O., Ceuleneer, G., Afonso, J. C. \& GréGoire, M. 2020: Reworking of old continental lithosphere: Unradiogenic Os and decoupled Hf-Nd isotopes in sub-arc mantle pyroxenites. Lithos 354, 105346. https://doi.org/10.1016/j.lithos.2019.105346

TOURET, J. L. R. 2001: Fluids in metamorphic rocks. - Lithos 55/1-4, 1-25. https://doi.org/10.1016/s0024-4937(00)00036-0

TUMiati, S. \& MALASPINA, N. 2019: Redox processes and the role of carbon-bearing volatiles from the slab-mantle interface to the mantle wedge. - Journal of the Geological Society 176/2, 388-397. https://doi.org/10.1144/jgs2018-046

Viti, C. \& Frezzotti, M. L. 2000: Re-equilibration of glass and $\mathrm{CO}_{2}$ inclusions in xenolith olivine: A TEM study. - American Mineralogist 85/10, 1390-1396. https://doi.org/10.2138/am-2000-1007

Van den Kerkhof, A. M., Touret, J. L. R., MaiJer, C. \& JAnSEn, J. B. H. 1991: Retrograde methane-dominated fluid inclusions from high-temperature granulites of Rogaland, southwestern Norway. - Geochimica et Cosmochimica Acta 55/9, $2533-2544$. https://doi.org/10.1016/0016-7037(91)90371-b

Vogel, D. E. 1967: Petrology of an eclogite- and pyrigarnite-bearing polymetamorphic rock complex at Cabo Ortegal, NW Spain. Leidse Geologische Mededelingen 40/1, 121-213.

Kézirat beérkezett: 2020. 11. 30. 
